\title{
O ENSINO DA CONSTITUIÇÃO FEDERAL NO ÂMBITO DO ENSINO MÉDIO INTEGRALIZADO DO INSTITUTO FEDERAL DE EDUCAÇÃO, CIÊNCIA E TECNOLOGIA DO AMAPÁ (IFAP)
}

\section{ARTIGO ORIGINAL}

COSTA, Pedro Henrique Maia1 ${ }^{1}$, COSTA, Susane de Almeida Aranha², FECURY, Amanda Alves ${ }^{3}$, DENDASCK, Carla Viana ${ }^{4}$, OLIVEIRA, Euzébio de ${ }^{5}$, DIAS, Claudio Alberto Gellis de Mattos ${ }^{6}$

COSTA, Pedro Henrique Maia. Et al. 0 ensino da constituição federal no âmbito do ensino médio integralizado do instituto federal de educação, ciência e tecnologia do Amapá (IFAP). Revista Científica Multidisciplinar Núcleo do Conhecimento. Ano 06, Ed. 04, Vol. 10, pp. 123-139. Abril de 2021. ISSN: 24480959, Link de acesso:

https://www.nucleodoconhecimento.com.br/educacao/integralizado-do-instituto, DOI: 10.32749/nucleodoconhecimento.com.br/educacao/integralizado-do-instituto

\section{RESUMO}

Nossa Constituição Federal de 1988 colocou a Educação como um Direito Fundamental no rol dos direitos sociais. Uma das finalidades da Educação, é

\footnotetext{
${ }^{1}$ Engenheiro Civil, Professor e pesquisador do Instituto de Ensino Básico, Técnico e Tecnológico do Amapá (IFAP), discente da Pós-Graduação Lato Sensu em Educação Profissional (IFAP).

${ }^{2}$ Advogada, Professora de Letras, Pós-graduada em Metodologia do Ensino da Língua Inglesa (UNITER) e Direito Civil e Empresarial (DAMASO).

${ }^{3}$ Biomédica, Doutora em Doenças Tropicais, Professora e pesquisadora do Curso de Medicina do Campus Macapá, Universidade Federal do Amapá (UNIFAP).

${ }^{4}$ Teóloga, Doutora em Psicanálise Clínica. Atua há 15 anos com Metodologia Científica ( Método de Pesquisa) na Orientação de Produção Científica de Mestrandos e Doutorandos. Especialista em Pesquisas de Mercado e Pesquisas voltadas a área da Saúde.

${ }^{5}$ Biólogo, Doutor em Doenças Tropicais, Professor e pesquisador do Curso de Educação Física da, Universidade Federal do Pará (UFPA).

${ }^{6}$ Biólogo, Doutor em Teoria e Pesquisa do Comportamento, Professor e pesquisador do Curso de Licenciatura em Química do Instituto de Ensino Básico, Técnico e Tecnológico do Amapá (IFAP) e do Programa de Pós Graduação em Educação Profissional e Tecnológica (PROFEPT IFAP).
}

$\mathrm{RC}: 83278$

Disponível em: https://www.nucleodoconhecimento.com.br/educacao/integralizadodo-instituto 
assegurar e preparar o aluno para o exercício do cidadão. As propostas em destaque não têm a finalidade de formar um bacharel em direito, mas sim, um cidadão consciente, que reconheça seus direitos e deveres básicos perante a sociedade e o Estado. O objetivo desta pesquisa é verificar a real possibilidade da introdução do estudo da Constituição Federal (CF) no IFAP, tendo como alicerce o conhecimento desses estudantes sobre noções básicas acerca da Constituição Federal. Foram utilizados questionários estruturados com perguntas fechadas e abertas, de caráter dissertativo e outras de caráter objetivo, aplicados no mês de janeiro de 2018 para os participantes envolvidos, com o auxílio do Google Forms. O Ensino Médio brasileiro, examinado a partir de um recorte pontual no curso técnico em edificações na forma integralizada do IFAP, campus Macapá, não consegue cumprir o que preconiza a CF e a LDB de acordo com o resultado do questionário aplicado aos estudantes. Este Ensino ocupa um lugar privilegiado na formação educacional brasileira, entre o fundamental e o superior. Os alunos demonstram estar entusiasmados com a possibilidade de implementação do ensino de Noções Básicas a CF no curso técnico em edificações no IFAP, campus Macapá, mesmo que de forma optativa.

Palavras-chave: EPT, Direito, Ensino, Constituição, Ensino Médio.

\section{INTRODUÇÃO}

Nossa Constituição Federal de 1988 colocou a Educação como um Direito Fundamental no rol dos direitos sociais, dessa forma consagrando constitucionalmente a sua importância para a formação e vida em sociedade. A Educação de uma população é uma condição imprescindível para o desenvolvimento de um Estado seja no âmbito social, cultural, econômico e científico (BRASIL, 2012).

A Constituição da República Federativa do Brasil 1988 (CFRB/1988), prescreve, em seu artigo $1^{\circ}$, que: "a República Federativa do Brasil, formada pela união indissolúvel 
dos Estados e Municípios e do Distrito Federal, constitui-se em Estado Democrático de Direito e tem como fundamentos: II - a cidadania; [...]"(BRASIL, 2012).

De acordo com ANTONELLO e NOREMBERG (2016), cidadania é um status no qual, se tem como objeto principal alcançar a plenitude do exercício dos direitos fundamentais inerentes ao indivíduo, status esse ligado de maneira intrínseca ao regime político, posto que, será através deste que o cidadão, por meio de seus representantes, alcançará seu direito às políticas públicas, ou seja, uma educação exemplar, saúde, segurança, entre outras.

A Lei de Diretrizes e Bases da Educação Brasileira (LDB 9394/96) é a legislação que regulamenta o sistema educacional (público ou privado) do Brasil, da educação básica ao ensino superior. Uma das finalidades da Educação, é assegurar e preparar o aluno para o exercício do cidadão, a ideia do presente artigo é discutir qual o melhor meio para chegar a essa finalidade, fundamentando e justificando todas as posições tomadas (BRASIL, 2016).

Em 16 de fevereiro de 2017, o atual presidente Michel Temer sancionou a Lei $\mathrm{n}^{\circ}$ 13.415 que Reforma o Ensino Médio, porém essa reforma dependerá diretamente da elaboração da nova Base Nacional Comum Curricular (BNCC), a qual deve ser homologada ainda este ano de 2018. novo ensino médio foi editado por meio de Medida Provisória (MP) seguindo rigorosamente as exigências previstas na Constituição Federal, porém alguns especialistas consideram essa forma de ação um retrocesso social, uma vez que as mudanças deveriam ter sido discutidas abertamente com a sociedade, e não implementadas via MP (BRASIL, 2017).

A Lei de Diretrizes e Bases da Educação Brasileira (LDB 9394/96), em seus artigos 2 e 22, estabelece que a educação tem por finalidade o pleno desenvolvimento do educando e seu preparo para o exercício da cidadania, assegurada por meio da educação básica. Mas para alcançarmos esse objetivo, torna-se imprescindível a democratização do conhecimento jurídico no seio da sociedade (BRASIL, 2016). 
$\mathrm{Na}$ busca por esse êxito, atualmente, o Direito vem sendo observado com outros olhos, não mais com uma visão positivista e restrita, mas agora como um conhecimento necessário e imprescindível para a vida do indivíduo. Porém é palpável o desconhecimento que uma parte significativa do povo brasileiro apresenta em relação às noções básicas da Constituição Federal, essa percepção foi confirmada por pesquisa do DataSenado feita com exclusividade para uma edição especial no ano de 2013 (SASSE, 2013).

Segundo MORAES (2013), "há inúmeros motivos para que sejam incluídas no ensino médio disciplinas jurídicas. Mas a basilar, é formar um cidadão, indivíduos formadores de opiniões, conhecedores dos seus direitos e de seus deveres". Contudo, se o intuito é a formação adequada dos cidadãos através do conhecimento jurídico, é prudente mostrar que, de certa forma, esta ideia já está sendo aderida no Brasil, mesmo que de forma incipiente e pontual.

O Estatuto da Criança e do Adolescente (ECA) foi instituído pela Lei no 8.069 no dia 13 de julho de 1990. Ela regulamenta os direitos e dispõe sobre a proteção integral das crianças e dos adolescentes inspirado nos princípios constitucionais. Embora o ECA seja uma lei que está em vigor desde 1990, tem havido uma série de dificuldades e desafios para a sua implementação na sociedade brasileira. Os principais responsáveis pela proteção e efetivação dos direitos da criança e do adolescente são, além da sociedade em geral, a família e o poder público (SARAIVA, 2017).

A Ordem dos Advogados do Brasil ( $O A B$ ) criou um projeto de ensino didático para as escolas do ensino médio do Brasil, chamado $O A B$ vai à Escola que se iniciou em 1993 por iniciativa do conselheiro da OAB SP e presidente da Comissão da Cidadania e Ação Social, na época, Nelson Alexandre da Silva Filho, na cidade de Osasco, e se expandiu para todo o Brasil, abrangendo cerca de 20 milhões de alunos da rede pública de ensino. Várias escolas públicas no Brasil foram contempladas pelo projeto, com o intuito de esclarecer o papel da própria OAB no 
Estado e o funcionamento deste, além de contribuir para a cidadania dos estudantes através de palestras, cartilhas, filmes educativos e, é claro, com debates que estimulem o interesse dos mesmos no conhecimento jurídico. (SILVA FILHO, 2004).

DIAS e DE OLIVEIRA (2015) apresentam algumas sugestões quanto aos conteúdos básicos do Direito que poderão ser integrados ao ensino regular, quais sejam, as noções de Direitos Humanos, do Estatuto da Criança e do Adolescente, Direitos do Consumidor, inclusive com ênfase no mercado eletrônico, Educação Fiscal e ainda, os caminhos da justiça.

Já MORAES (2013) acredita que seria de grande valor social a inserção no ensino médio das seguintes disciplinas: Introdução ao Direito, Direitos e Garantias Constitucionais, Direito Penal, Direito Civil e Leis Esparsas, como o estudo de algumas leis como o Estatuto da Criança e do Adolescente. $O$ aluno necessitaria também, possuir conhecimentos básicos, sobre Administração Pública, hierarquia dos poderes, a criação e promulgação de leis.

As propostas em destaque não têm a finalidade de formar um bacharel em direito, mas sim, um cidadão consciente, que reconheça seus direitos e deveres básicos perante a sociedade e o Estado.

\section{OBJETIVO}

Verificar a real possibilidade da introdução do estudo da Constituição Federal (CF) no IFAP, tendo como alicerce o conhecimento desses estudantes sobre noções básicas acerca da Constituição Federal.

\section{MÉTODO}

Foram utilizados questionários estruturados com perguntas fechadas e abertas, de caráter dissertativo e outras de caráter objetivo, aplicados no mês de janeiro de 2018 para os participantes envolvidos, com o auxílio do Google Forms. 
O público alvo foi composto de 20 docentes do colegiado do curso técnico em edificação na forma integralizada, pedagogos e coordenadores dos cursos técnicos na forma integralizada, o diretor de ensino e o diretor geral do IFAP, campus Macapá, além de alguns advogados pertencentes a OAB no estado do Amapá, funcionários do próprio IFAP. Outro questionário com perguntas fechadas, de caráter objetivo, foi aplicado a 106 discentes dos cursos técnicos de edificações do IFAP no campus Macapá sem aviso prévio, dividido em cinco seções para verificar o grau de conhecimento que os mesmos apresentavam em relação à visibilidade social dos três poderes na esfera municipal, às noções básicas sobre a Constituição Federal e com relação aos princípios de justiça, decorrentes dos costumes e/ou senso comum de uma sociedade.

\section{RESULTADOS E DISCUSSÃO}

Tanto a análise quantitativa quanto a qualitativa procurou agrupar as questões por seções específicas de quesitos a serem investigados para facilitar a interpretação dos dados e discussão dos resultados.

\section{QUESTIONÁRIO APLICADO AO CORPO TÉCNICO DO IFAP}

Analisando a figura 01, podemos observar que a maioria dos participantes deste questionário estão na faixa dos trinta anos, sendo que a maioria tem 32 anos. Esse resultado é decorrente do IFAP ser uma instituição recente, onde há o ingresso constante de profissionais parar atender à crescente demanda do público alvo (IFAP, 2021). 
Figura 01 № entrevistados segundo a idade.

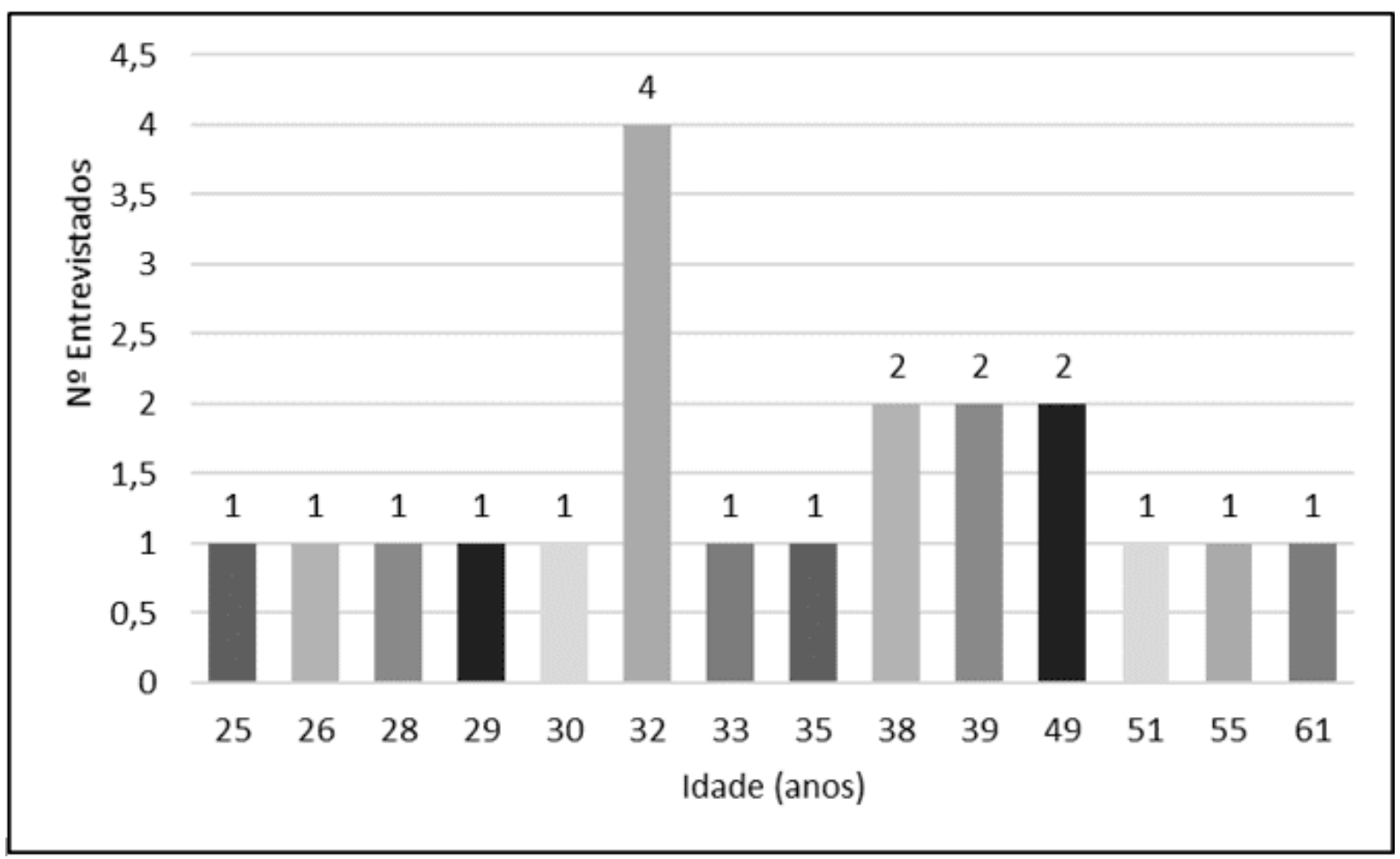

RC: 83278

Disponível em: https://www.nucleodoconhecimento.com.br/educacao/integralizadodo-instituto 
Figura 02: Percentual de entrevistados segundo ao sexo.

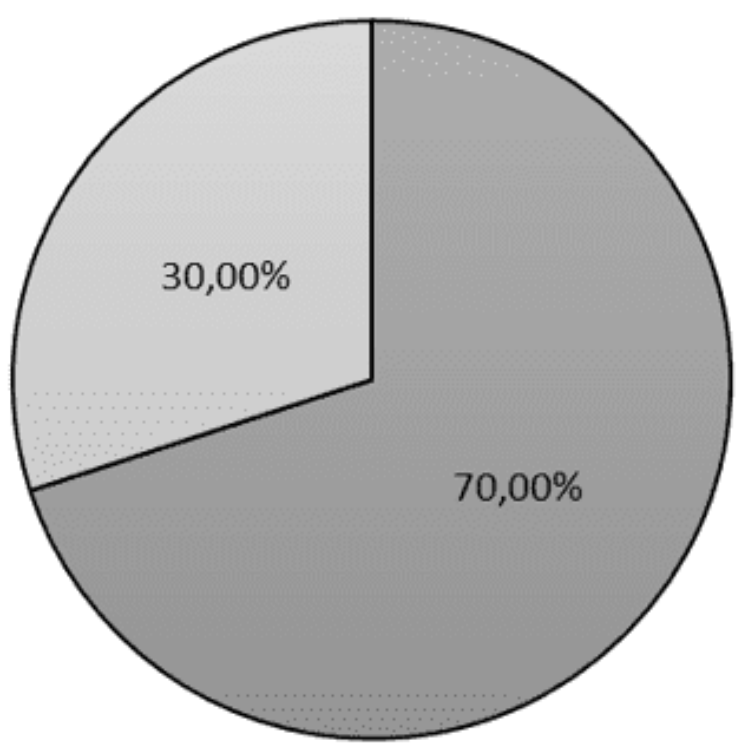

$\square$ Masculino $\square$ Feminino

Já na Figura 02, verificamos uma maior quantidade de entrevistados do sexo masculino, mais que o dobro de mulheres, fato que não foi evidenciado no resultado do questionário aplicado aos discentes, o qual demonstrou certa homogeneidade com relação ao gênero. Isso é reflexo do maior número de homens existentes no mercado de trabalho brasileiro (NÓBREGA et al., 2019).

Quanto a profissão/cargo, a Figura 03 apresenta um resultado já esperado, no qual a maior quantidade dos entrevistados foram professores da base nacional comum de ensino do curso técnico em edificações, uma vez que as disciplinas da BNCC acumulam aproximadamente $69 \%$ da carga horária total do curso (IFAP, 2019). 
Figura 03 № entrevistados segundo a profissão /cargo.

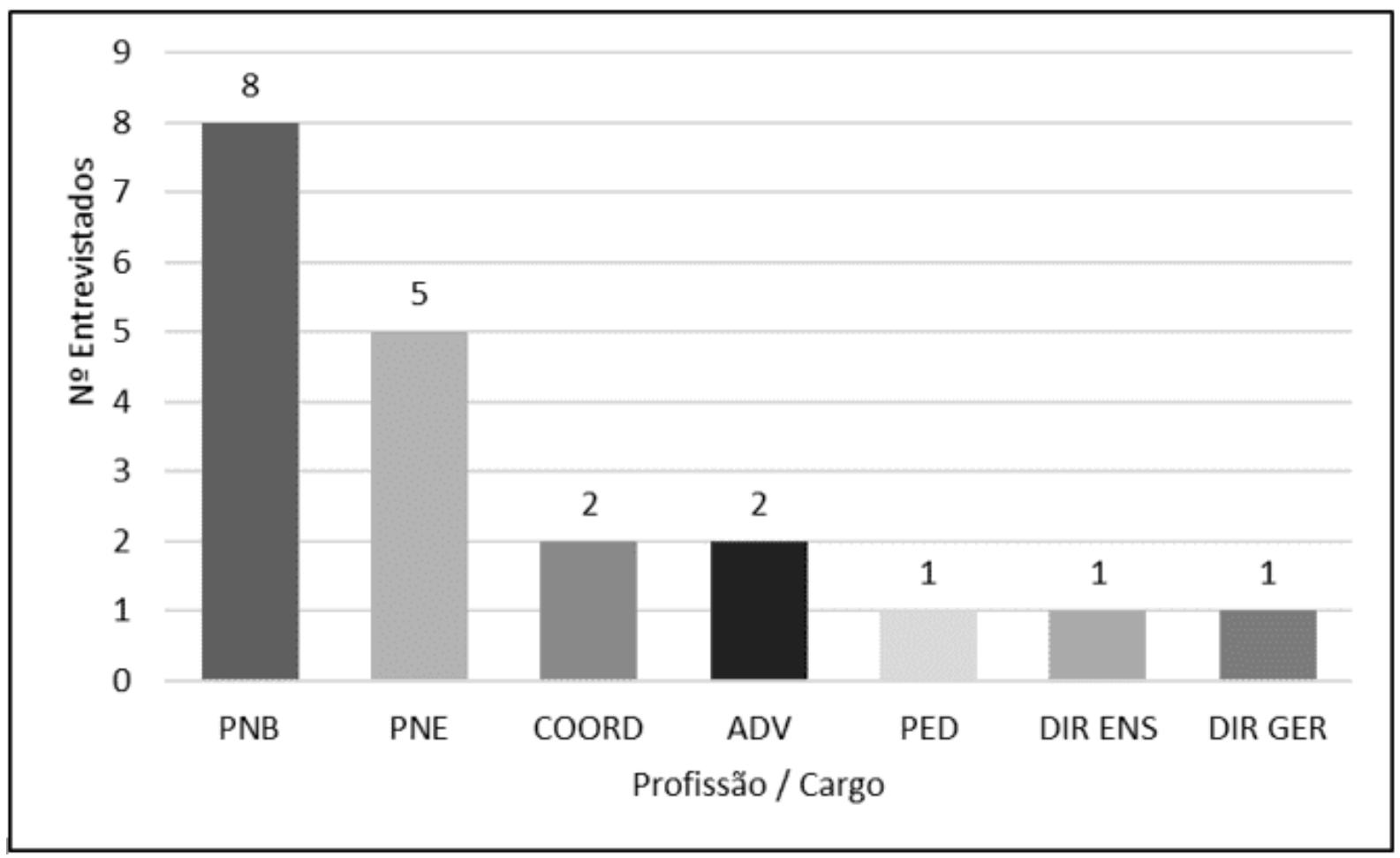

RC: 83278

Disponível em: https://www.nucleodoconhecimento.com.br/educacao/integralizadodo-instituto 
Figura 04 № entrevistados segundo ao tempo de experiência profissional.

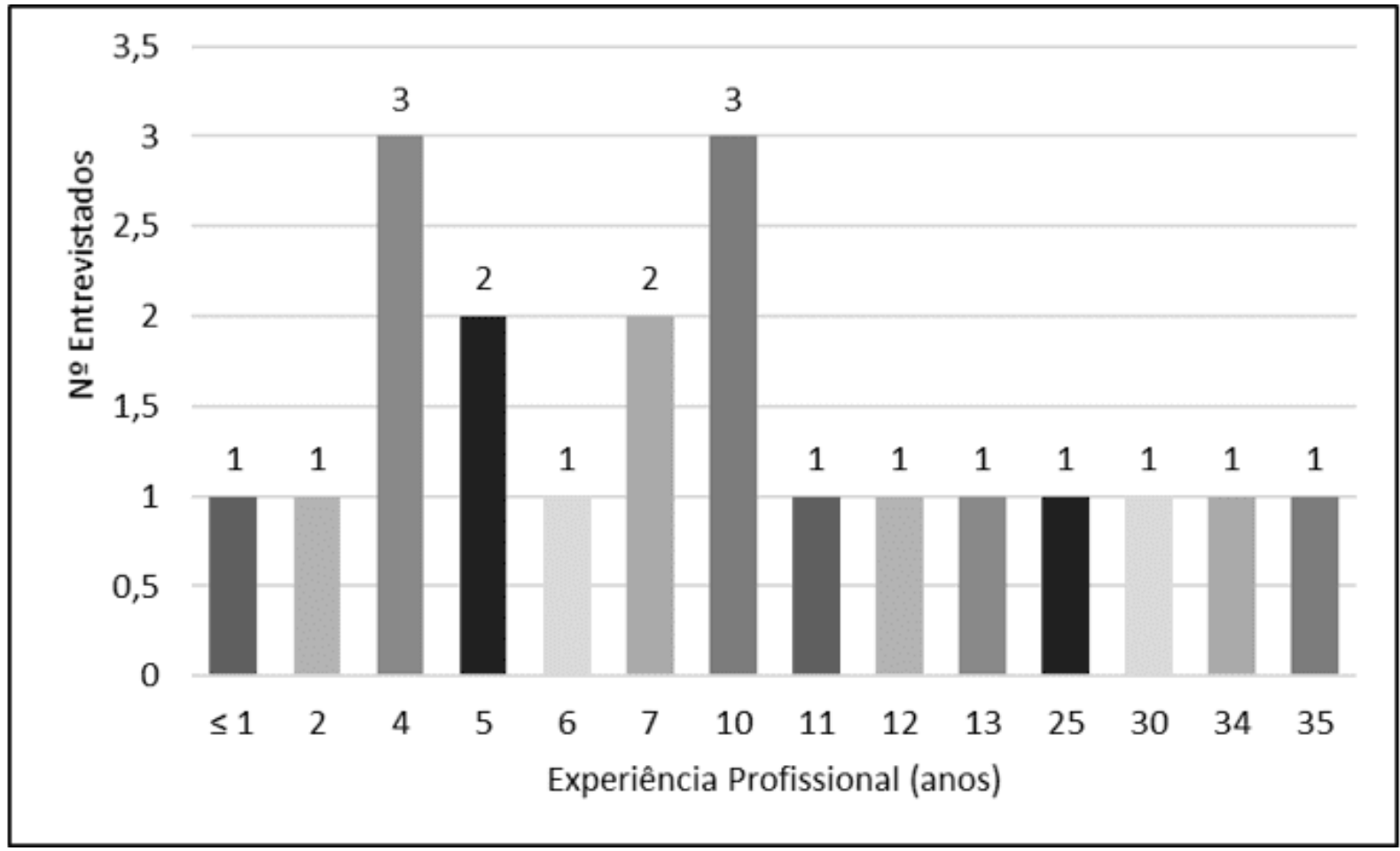

$\mathrm{Na}$ figura 04 notamos que a maioria dos entrevistados não possui larga experiência profissional, mesmo assim os resultados são considerados bastante relevantes, pois todos os entrevistados são funcionários públicos que não precisam omitir ou distorcer as respostas por motivos alheios (BRASIL, 1990).

Os entrevistados quando perguntados se já haviam lido ou manuseado (folheado) a $\mathrm{CF}, 90 \%$ responderam positivamente, conforme evidenciado na figura 05 e a maioria relatou que a parte que Ihes chamou mais atenção foi a "Dos Direitos e Garantias Fundamentais", principalmente $o$ artigo $5^{\circ}$ e o direito social a educação, elencado no artigo 6으. mostrando que a maioria dos profissionais acessam a Carta Magna para conhecerem sobre seus direitos e garantias e, logicamente, sobre a área da educação, já que a maioria dos entrevistados são professores e atuam na área da docência (BRASIL, 1990). 
Figura 05 Percentual de entrevistados que já leram ou manusearam (folhearam) a CF.

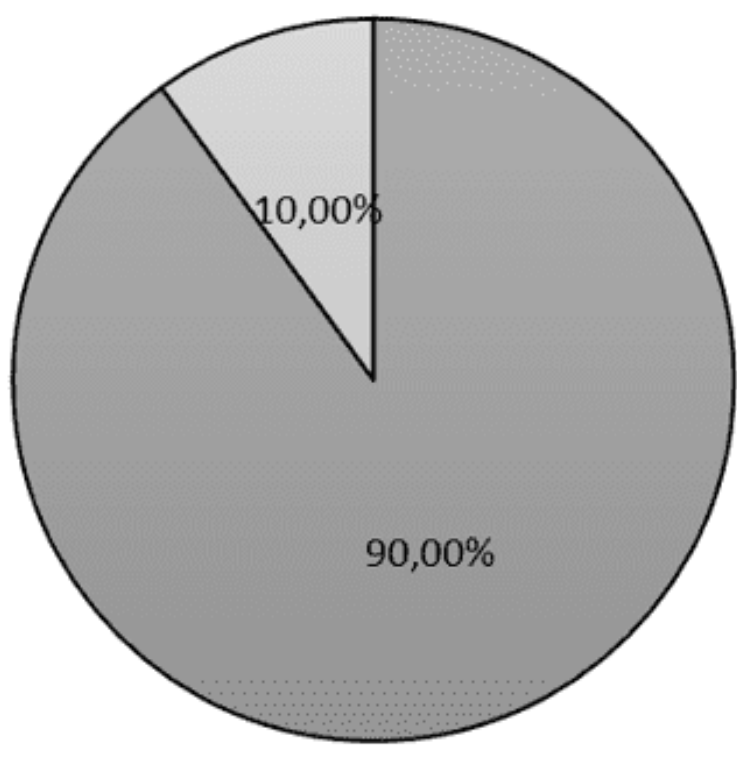

पSim पNão

Quanto ao grau de conhecimento que os participantes da entrevista consideram possuir em relação a CF de 1988, 55\% deles consideram possuir um conhecimento insuficiente para o exercício pleno da cidadania, 40\% consideram possuir conhecimento suficiente e apenas um advogado considerou possuir um excelente conhecimento de nossa Constituição Federal, o que era de se esperar, pois atua diretamente com o assunto indagado, este resultado pode ser evidenciado nas figura 06, a qual demonstra um equilíbrio sobre o grau de conhecimento dos participantes em relação a CF (FONSECA e FERNANDES, 2020). 
Figura 06 Grau de conhecimento em relação a CF de 1988 - A) quantidade de entrevistados; B) percentual de entrevistados.
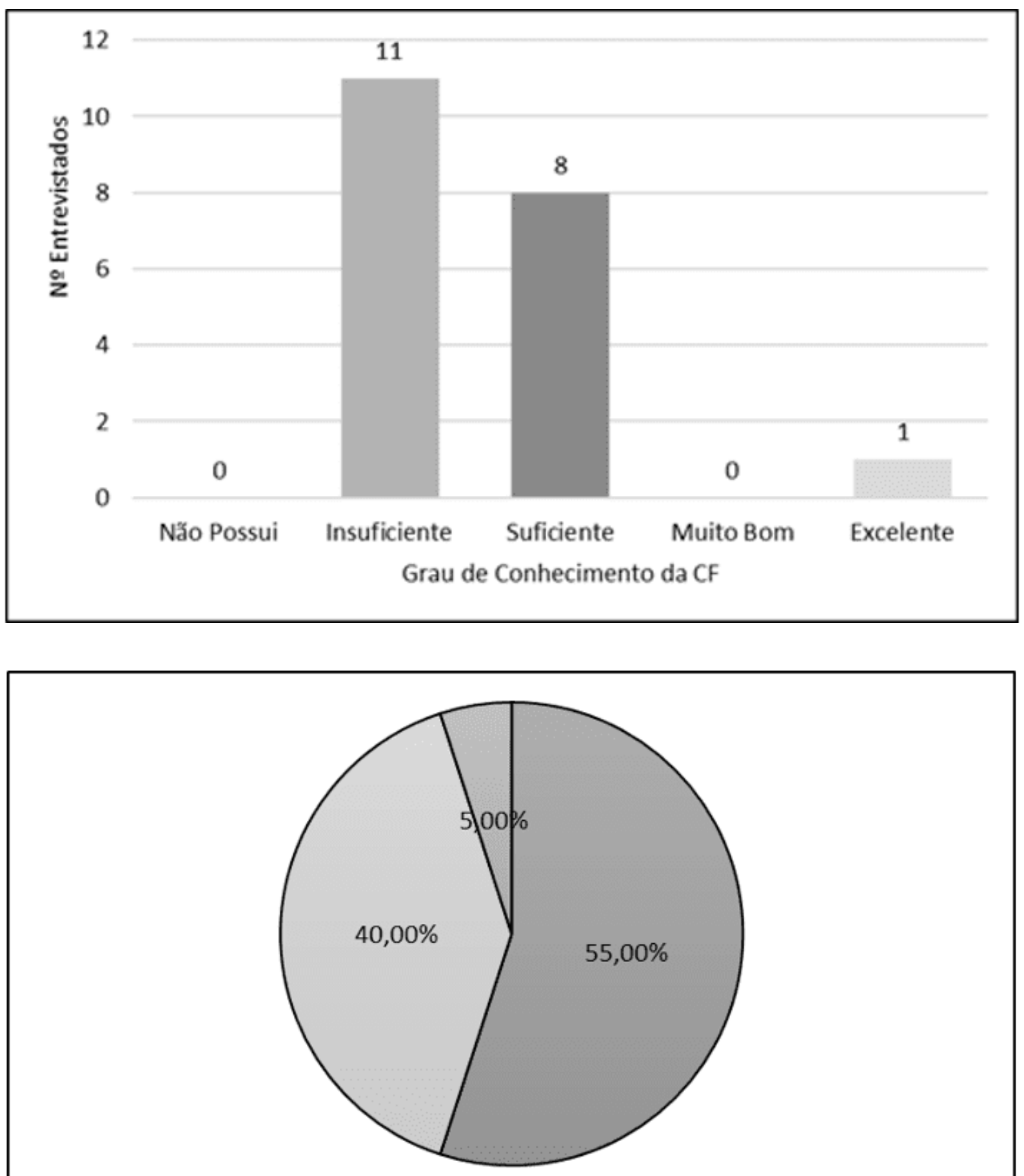

口Insuficiente $\square$ Suficiente $\square$ Excelente

RC: 83278

Disponível em: https://www.nucleodoconhecimento.com.br/educacao/integralizadodo-instituto 
Ao serem indagados sobre a relevância do ensino de Noções Básicas da Constituição Federal na educação básica atual, a grande maioria considerou esse ensino de extrema importância para os estudantes mesmo que em sua forma básica, contribuindo para o crescimento intelectual e humanístico dos estudantes (LORENSET et al., 2021).

Com relação ao conhecimento de algum projeto de lei proposto na tentativa de formalizar o ensino do Direito nas escolas, apenas 20\% responderam ter conhecimento (figura 07) e citaram principalmente o projeto de lei do Senador Romário, embora que de forma superficial, constatou-se que esse projeto de lei é o mais conhecido junto à comunidade acadêmica (ROMARIO, 2021).

Figura 07 Percentual dos entrevistados que conhecem algum projeto de lei na tentativa de formalizar o ensino do Direito nas escolas.

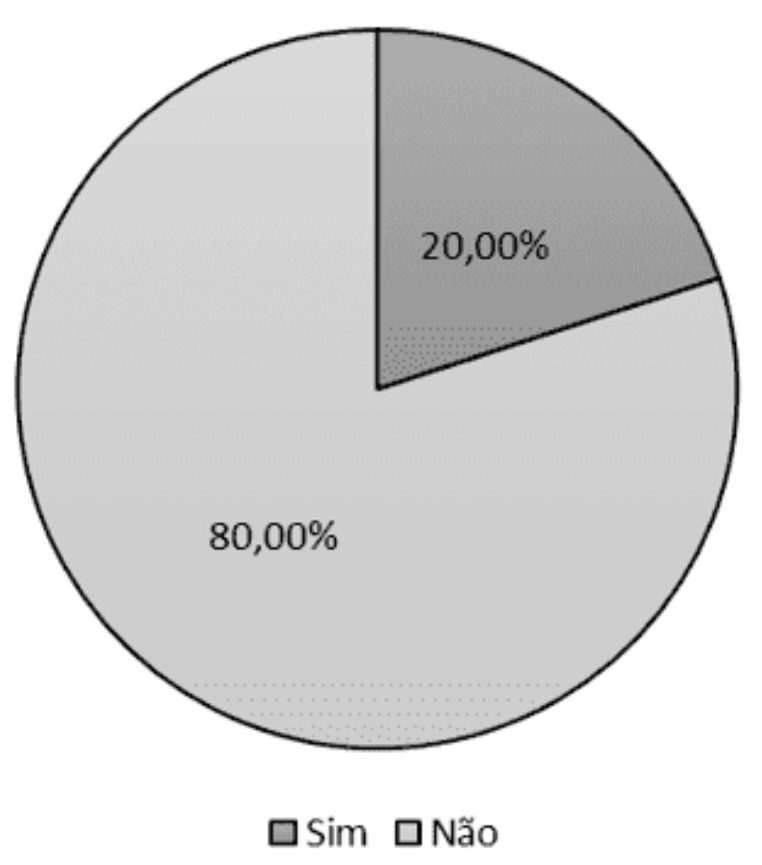

Quando abordados sobre os conteúdos de Noções Básicas da Constituição Federal que deveriam ser ensinados aos alunos da educação básica, os principais assuntos 
citados foram: Direitos e Garantias Fundamentais, Cidadania, Princípios Fundamentais, Estatuto da Criança e do Adolescente e Direitos Humanos. Do ponto de vista de $40 \%$ dos entrevistados, esses conteúdos deveriam ser estudados tanto no ensino fundamental quanto no ensino médio e, conforme mostra a figura 08 , nenhum entrevistado optou pela alternativa de estudar esses conteúdos somente no ensino superior, o que já demonstra uma tendência favorável de se implantar esse ensino na educação básica (HOHENDORFF et al., 2020).

Figura 08 Opinião sobre a etapa que o Ensino de Noções Básicas da CF deve ser estudado - a) quantidade de entrevistados; b) percentual de entrevistados.

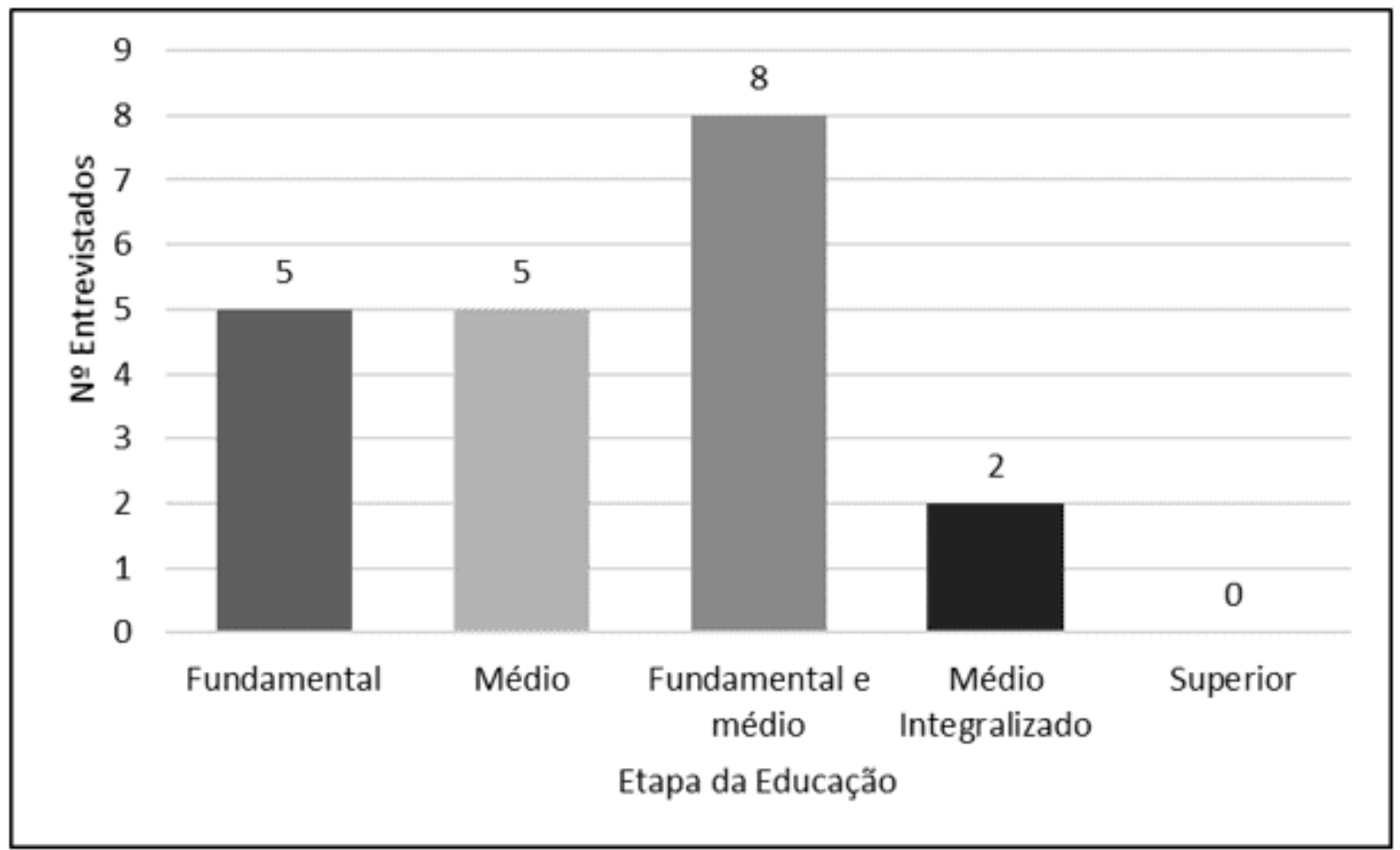

RC: 83278

Disponível em: https://www.nucleodoconhecimento.com.br/educacao/integralizadodo-instituto 


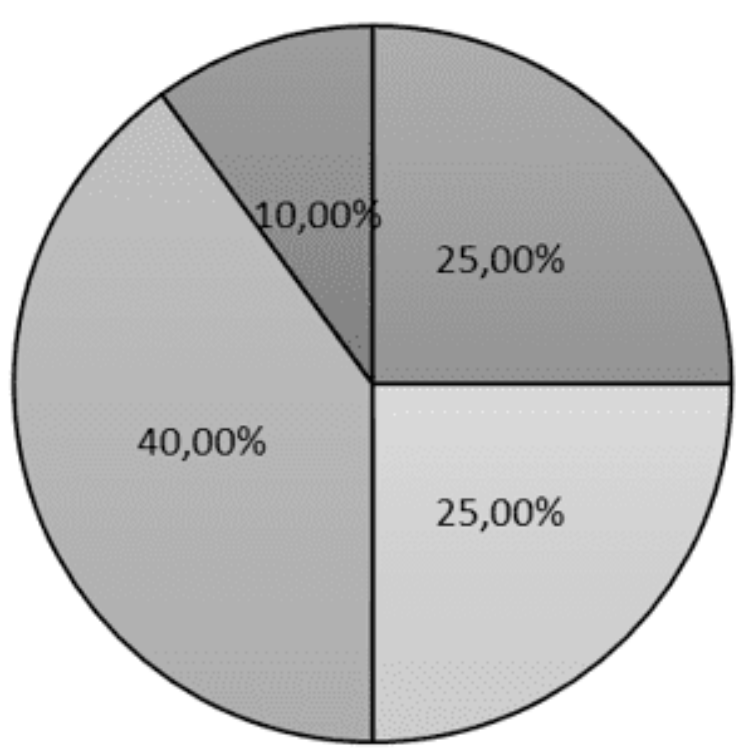

Gundamental aMédio $\square$ Fundamental e médio $\square$ Médio Integralizado

Os entrevistados foram perguntados se já tiveram ao longo de sua vida acadêmica a oportunidade de estudar disciplinas como Organização Social e Política do Brasil (OSPB) e Educação Moral e Cívica (EMC), 55\% dos entrevistados nunca estudaram tais disciplinas e $45 \%$ tiveram a oportunidade de estudá-las ao longo de sua vida acadêmica. Isso reflete a idade dos entrevistados, pois aqueles com mais de 35 anos, provavelmente concluíram a educação básica ainda na época do Regime Militar, período em que essas disciplinas eram amplamente difundidas na educação básica das escolas públicas (AMARAL e CASTRO, 2020). A maioria dos entrevistados que responderam positivamente à questão argumentaram que estas disciplinas contribuíram para a formação de um pensamento mais crítico, indivíduos mais conscientes de seus direitos e deveres e mais preparados para o exercício da cidadania (TAVARES et al., 2020).

Segundo a possibilidade de implementar o ensino de noções básicas da Constituição Federal no atual cenário da educação brasileira, apenas dois entrevistados, um professor do núcleo comum e um do núcleo específico, foram contrários a essa proposta, alegando uma carga horária elevada na educação 
básica e pelo fato dessa proposta ter que partir do Ministério da Educação (MEC) para poder ser implementada, caso contrário ela seria inviabilizada. Por outro lado, a maioria dos entrevistados foram favoráveis a proposta, alegando que o avanço tecnológico facilitaria esse ensino, além de promover uma mudança gradativa no atual cenário político brasileiro e um aumento na conscientização dos cidadãos sobre seus direitos e deveres (TAVARES et al., 2020).

\section{QUESTIONÁRIO APLICADO A DISCENTES DE CURSO TÉCNICO DO IFAP}

$\mathrm{Na}$ figura 9 podemos evidenciar que a maioria dos estudantes que participaram da pesquisa possuem faixa etária entre 15 e 18 anos, isso ocorre pelo fato de que os entrevistados são alunos do ensino médio na forma integralizada que se enquadram nessa faixa etária. Detectamos, também, que a maioria dos participantes tinham 15 anos de idade, esse resultado é confirmado por meio do gráfico da figura 10, o qual explicita que a maioria dos estudantes que responderam o questionário estão matriculados no $1^{\circ}$ ano, ou seja, são alunos iniciantes do ensino médio com idade média de 15 anos (IFAP, 2019). 
Figura 09 Distribuição dos estudantes participantes segundo a idade.

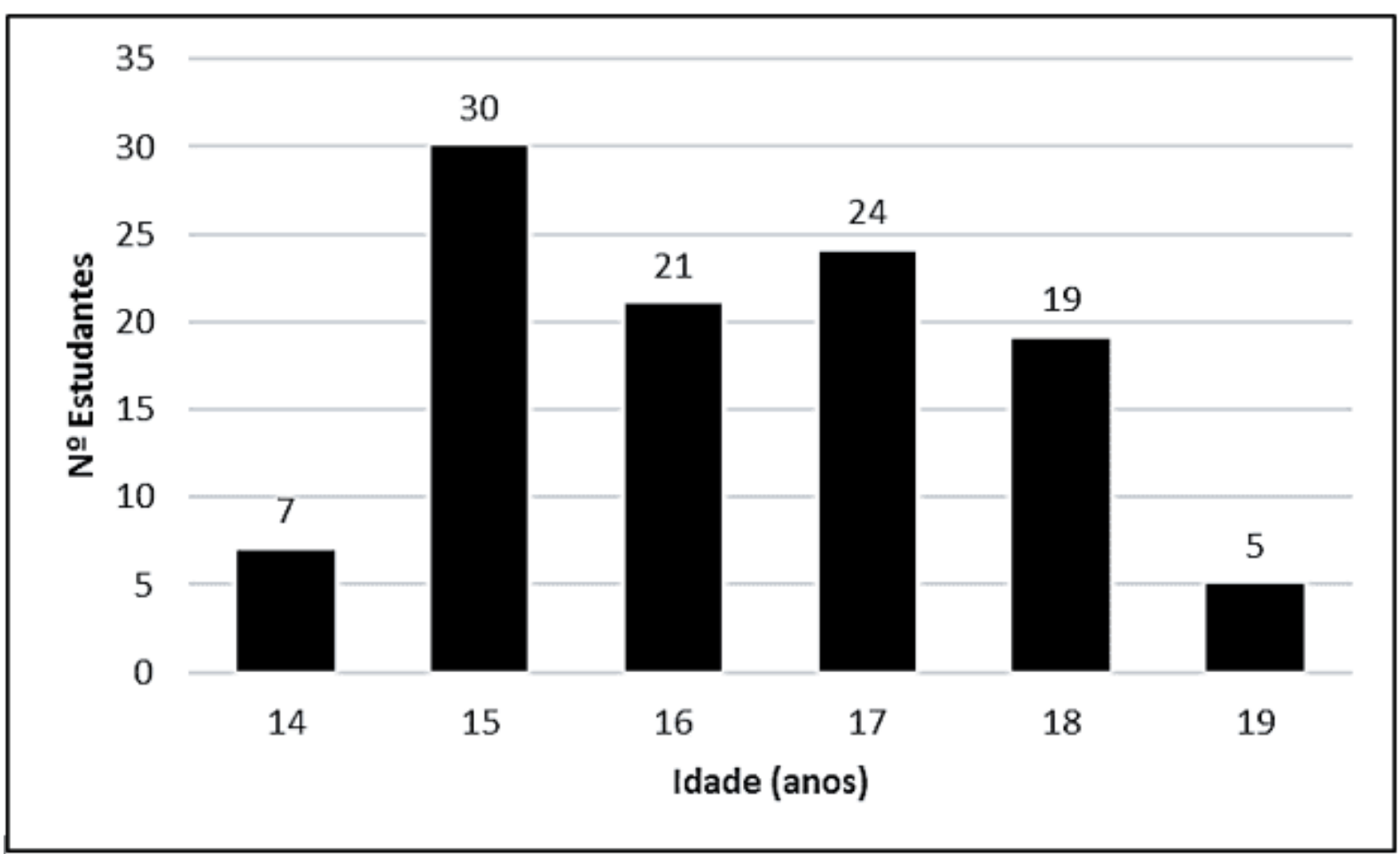

RC: 83278

Disponível em: https://www.nucleodoconhecimento.com.br/educacao/integralizadodo-instituto 
Figura 10 Distribuição dos estudantes participantes segundo a série/ano.

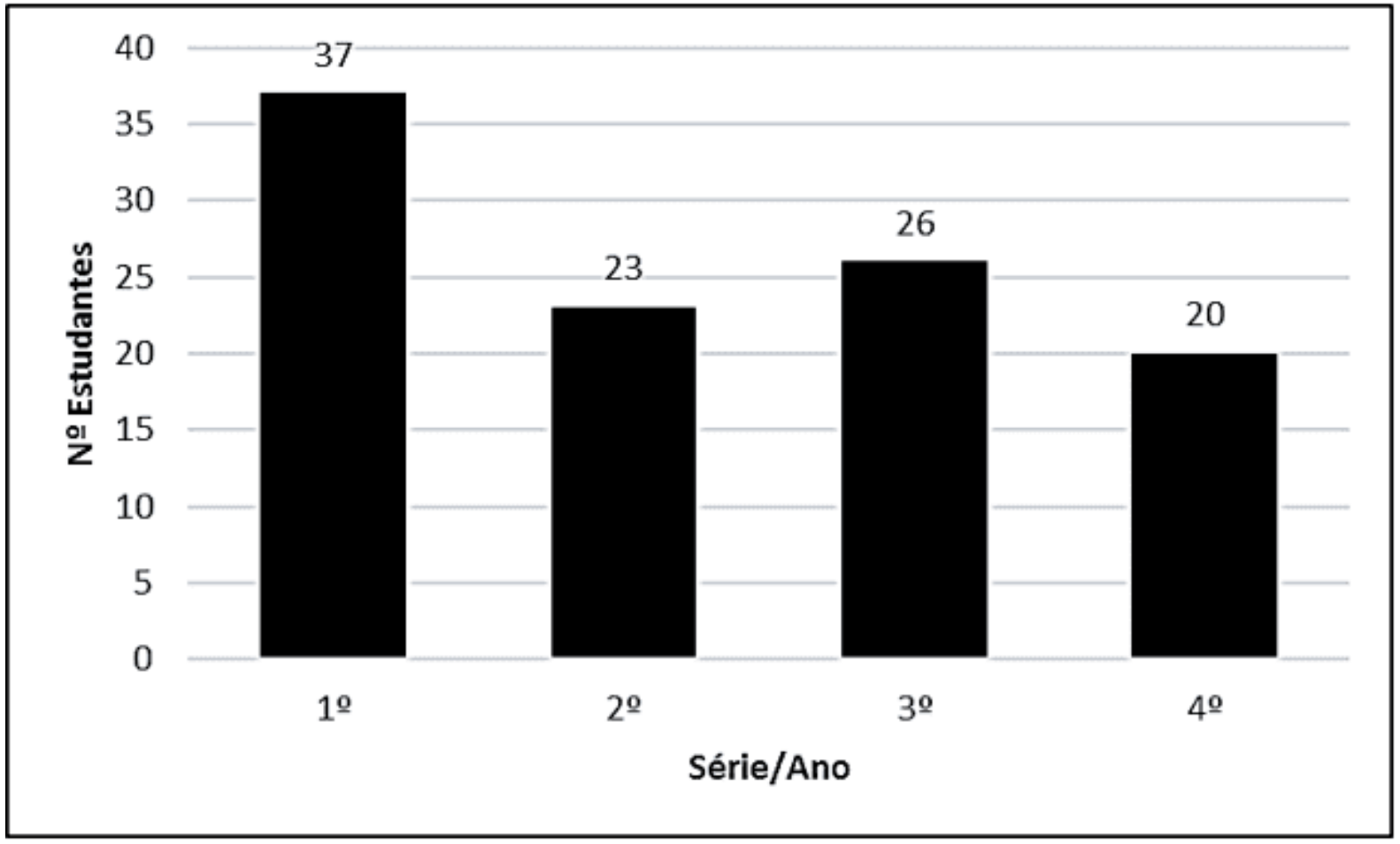

Dos 106 estudantes que participaram da pesquisa, 56 são do sexo masculino e 50 são do sexo feminino, o que demonstram um equilíbrio com relação ao gênero dos entrevistados, este resultado pode ser evidenciado na figura 11, onde estes números retratam que $52,83 \%$ dos entrevistados são do sexo masculino e $47,17 \%$ são do sexo feminino (IBGE, 2010).

Quanto a renda familiar, nota-se na figura 12 que a maioria do público entrevistado pertence à classe pobre. Esse é o público do ensino médio na forma integralizada do IFAP, independente do campus ou curso, refletindo de maneira análoga a pirâmide de renda do Brasil (IBGE, 2021).

RC: 83278

Disponível em: https://www.nucleodoconhecimento.com.br/educacao/integralizadodo-instituto 
Figura 11 Distribuição dos estudantes participantes segundo o sexo.

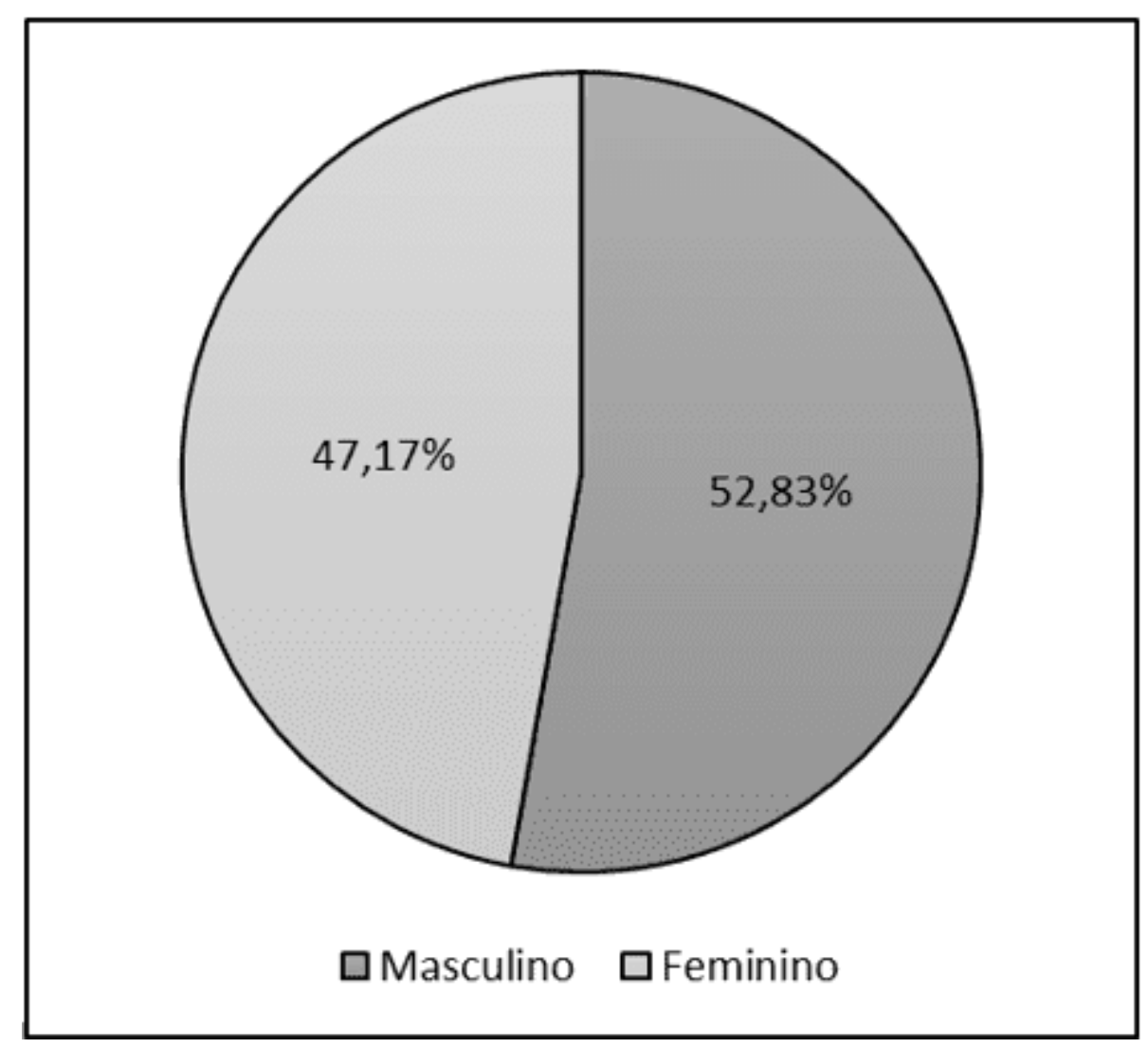

RC: 83278

Disponível em: https://www.nucleodoconhecimento.com.br/educacao/integralizadodo-instituto 
Figura 12 Distribuição dos estudantes participantes segundo a renda familiar.

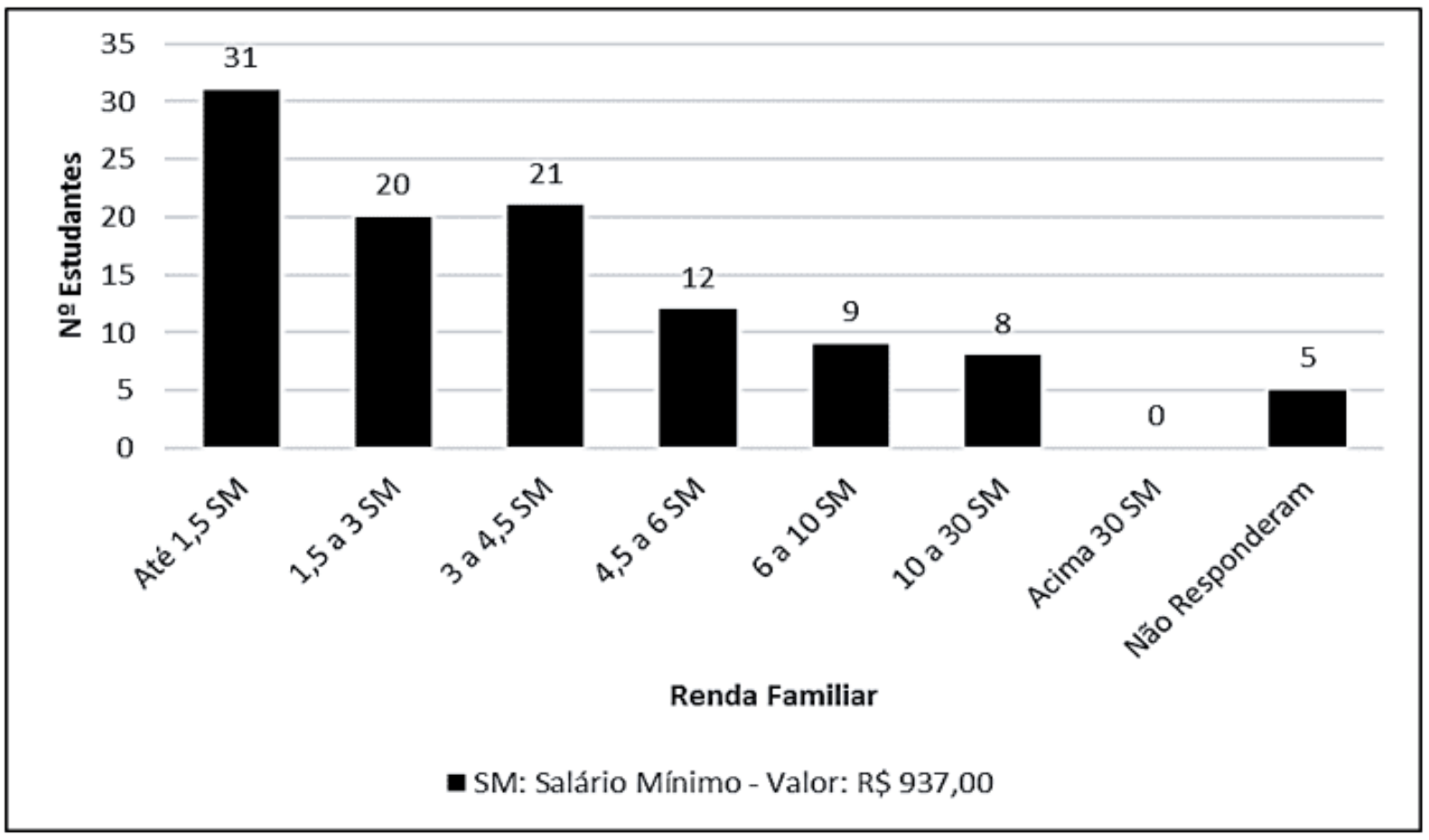

Perguntou-se pela localização espacial dos três poderes em Macapá. O conhecimento da localização dos três poderes no espaço urbano é evidência da importância social de que dispõem. O resultado demonstrou que o executivo é o mais visível, seguido do legislativo e por último o judiciário, conforme gráfico apresentado na figura 13 , onde $44,65 \%$ dos entrevistados responderam corretamente as questões sobre a notoriedade do Poder Executivo. Esse reflexo da visibilidade social dos três poderes é decorrente de um maior investimento por parte do executivo e legislativo nos meios de comunicação do que o poder judiciário, principalmente pelo fato de seus ocupantes serem eleitos pelo povo, o que torna essa notoriedade cada vez mais necessária para a sua promoção pessoal, enquanto que os ocupantes do judiciário, em sua maioria, tomam posse via concurso público, ou seja, estão amparados pelo princípio da meritocracia para exercer o cargo e não necessitam do voto popular (FIGUEIREDO, 2019). 
Figura 13 Visibilidade social dos três poderes constituintes em Macapá.

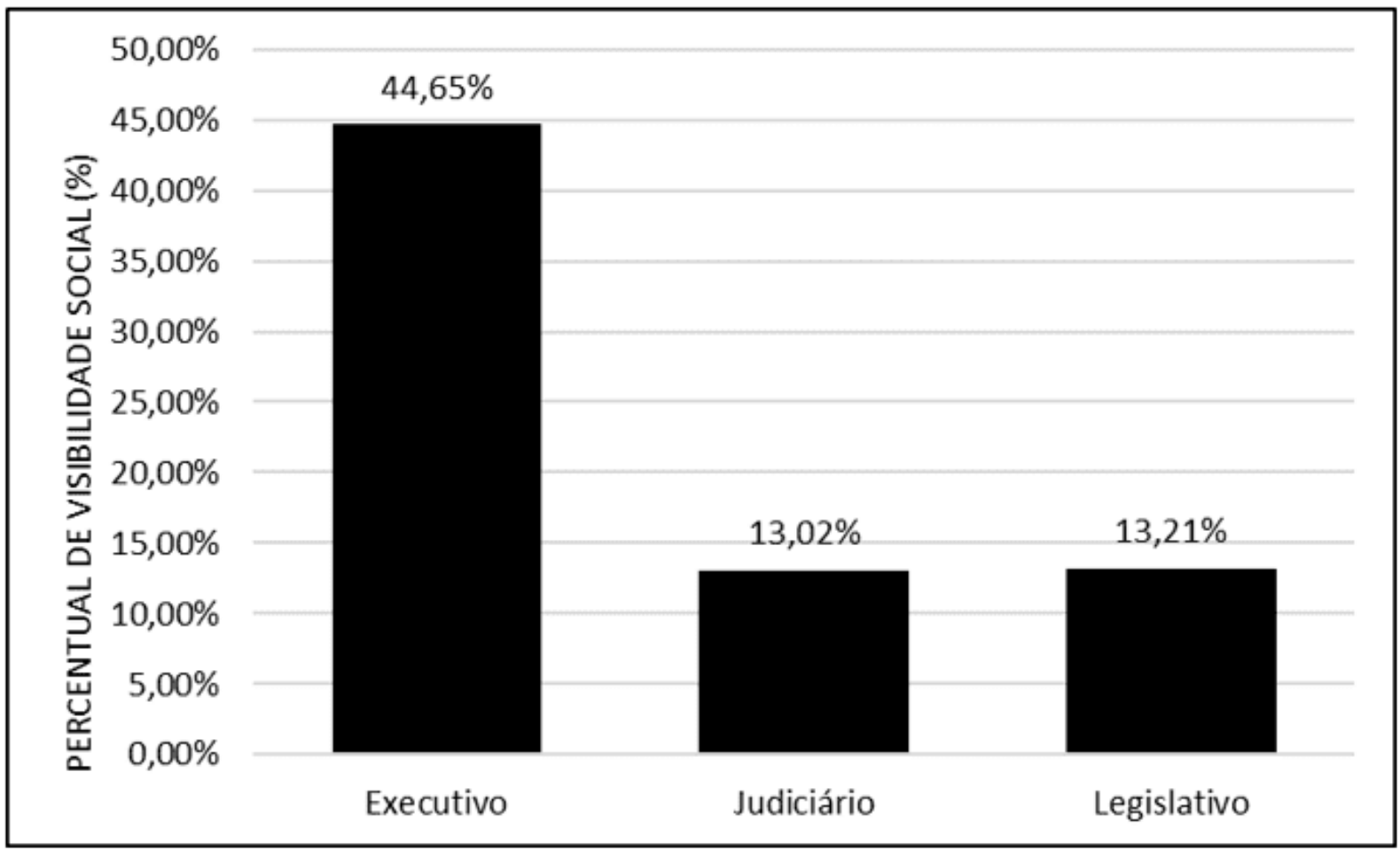

As quatro figuras abaixo (14 a 17) fazem uma correlação entre a visibilidade social dos 3 poderes em Macapá e os fatores que poderiam influenciar nesse índice de notoriedade. Dentre os 4 fatores pesquisados, o que apresentou uma linha de tendência mais evidente foi aquele que relacionou a visibilidade social e a série/ano dos participantes, evidenciada na figura 15, onde detectou-se que a visibilidade social dos 3 poderes aumenta à medida que os alunos passam para a série seguinte.

RC: 83278

Disponível em: https://www.nucleodoconhecimento.com.br/educacao/integralizadodo-instituto 
Figura 14 Visibilidade social dos três poderes constituinte em Macapá segundo a idade.

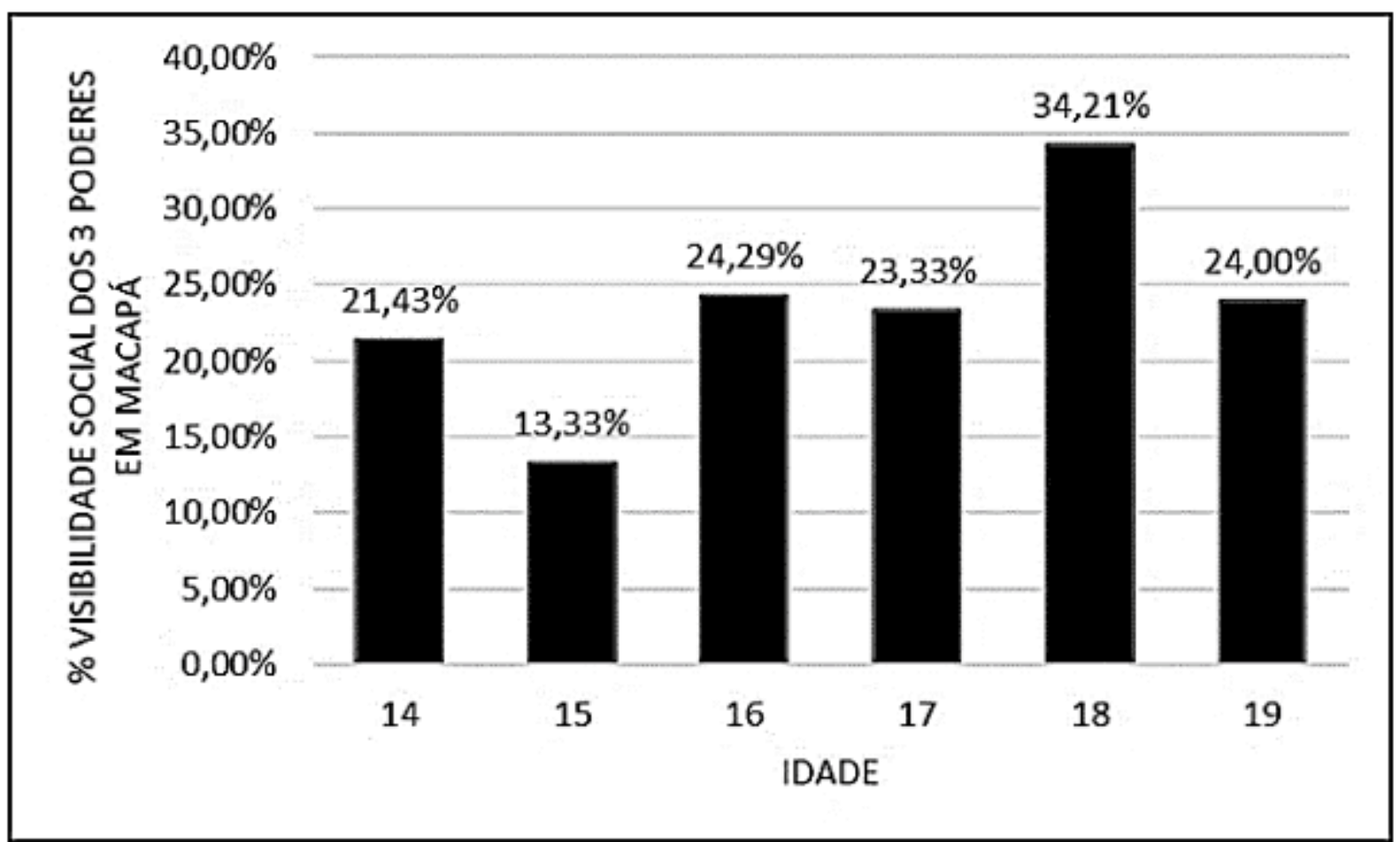

RC: 83278

Disponível em: https://www.nucleodoconhecimento.com.br/educacao/integralizadodo-instituto 
Figura 15 Visibilidade social dos três poderes constituinte em Macapá segundo a série/ano.

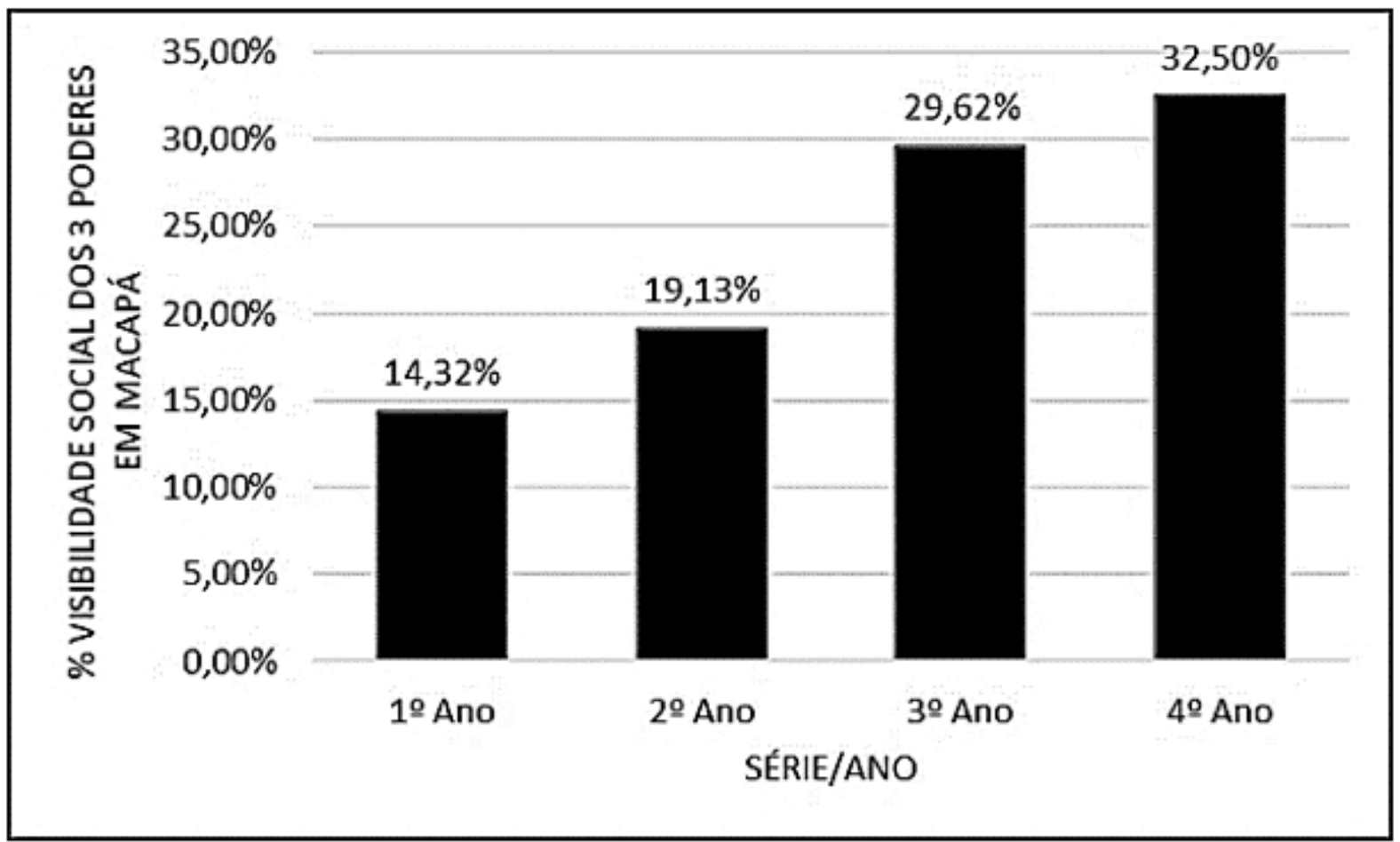

RC: 83278

Disponível em: https://www.nucleodoconhecimento.com.br/educacao/integralizadodo-instituto 
Figura 16 Visibilidade social dos três poderes constituinte em Macapá segundo a idade.

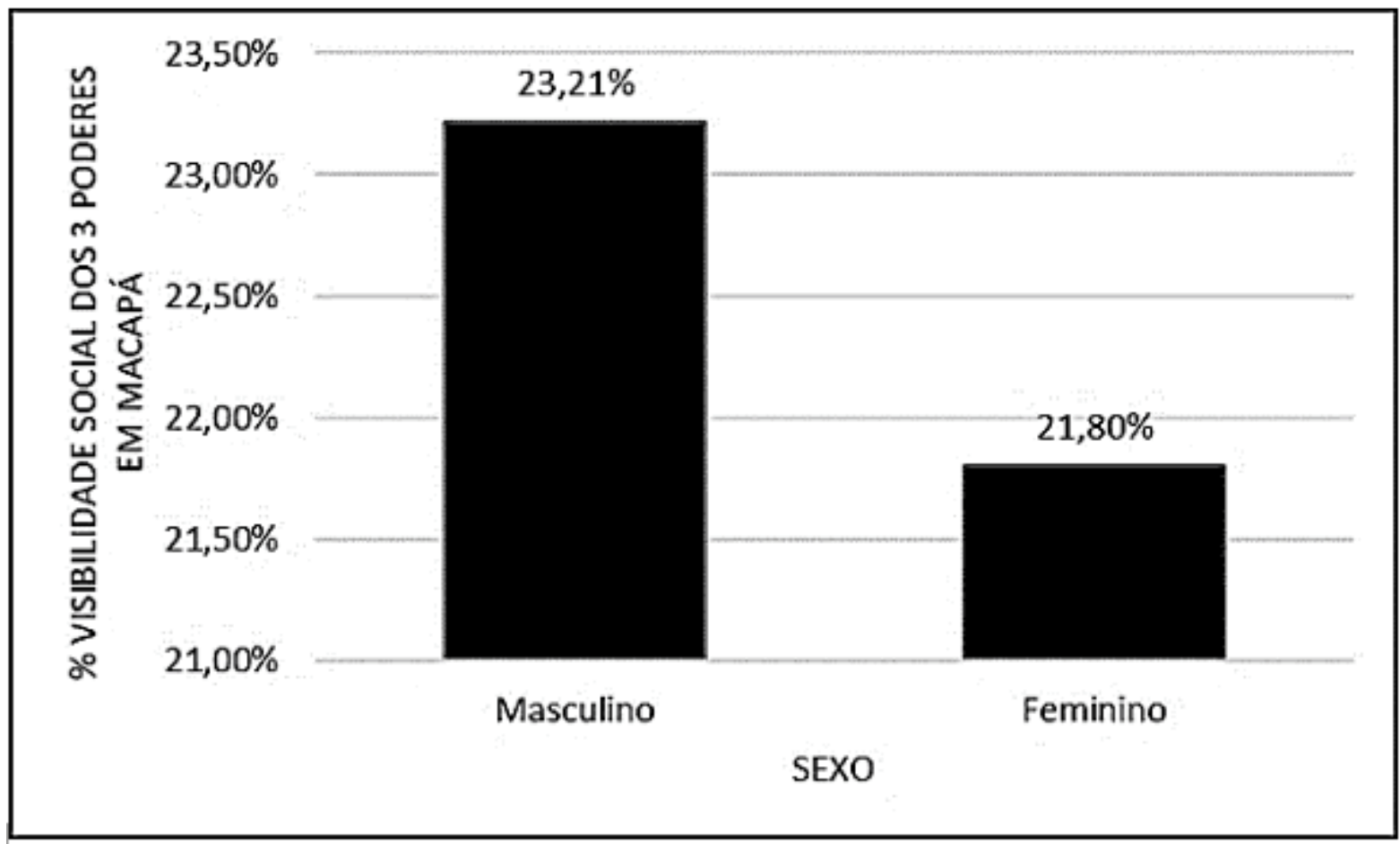

RC: 83278

Disponível em: https://www.nucleodoconhecimento.com.br/educacao/integralizadodo-instituto 
Figura 17 Visibilidade social dos três poderes constituinte em Macapá segundo a idade.

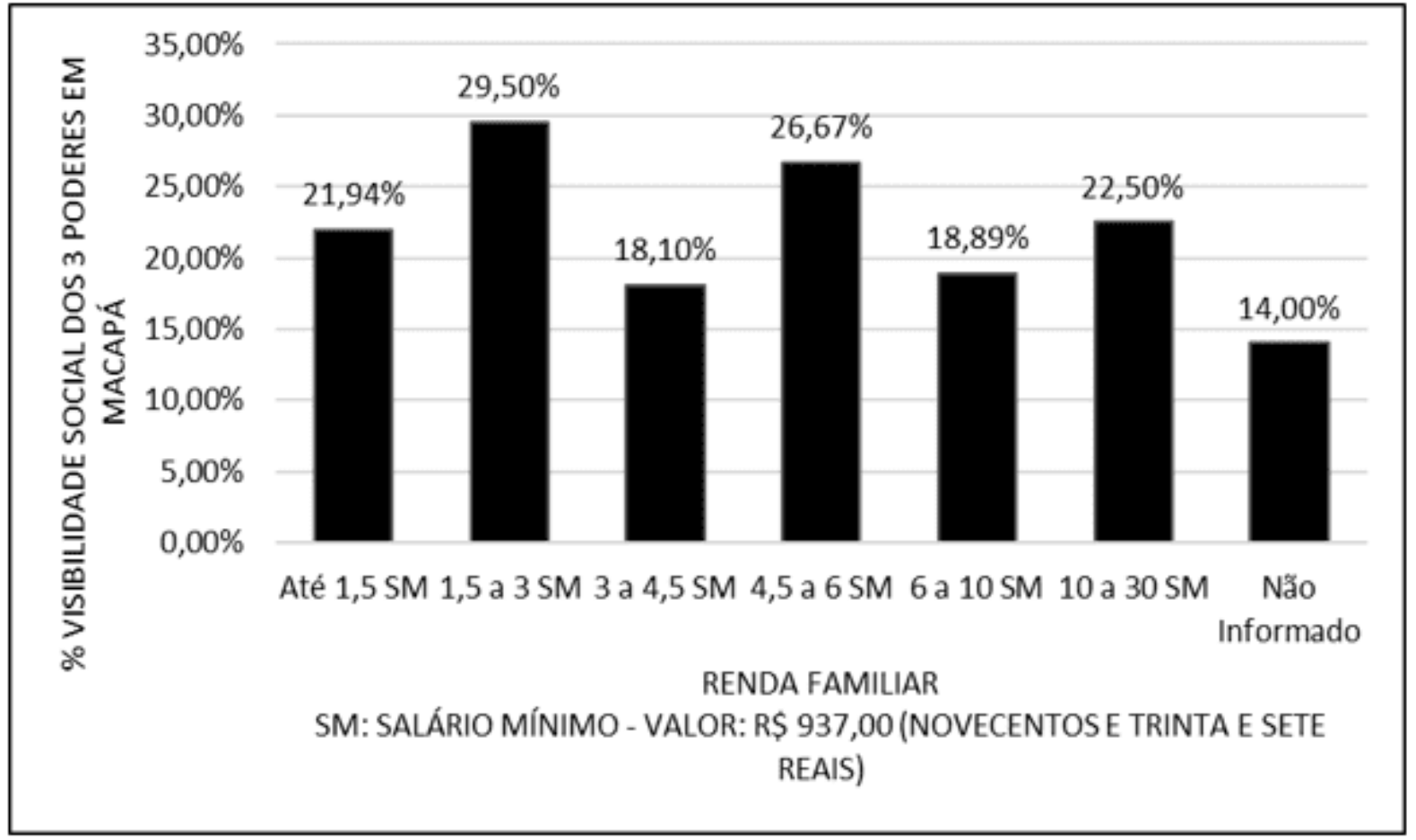

Esse resultado pode ser decorrente de conhecimentos adquiridos na escola, junto a família ou perante a sociedade, que com o maior convívio social que os alunos vão adquirindo com ao longo de suas vidas, acabam por assimilar maior quantidade de informações sobre os poderes constituintes (SILVA FILHO, 2004).

$\mathrm{Na}$ figura 18, podemos constatar que $49,01 \%$ das respostas escolhidas pelos entrevistados foram equivocadas, isso sem levar em consideração o percentual de $5,38 \%$ de respostas em branco, as quais provavelmente os participantes não sabiam a resposta correta. Isso mostra que o texto constitucional continua sendo reduto de especialistas e que a grande maioria dos estudantes provavelmente nunca sequer manuseou a Constituição Federal, o que significa que ela não compõe a realidade do ensino médio na forma integralizada. Ela não é trabalhada, discutida pelos estudantes. Por conseguinte, fica fácil presumir que certamente também desconhecem seus direitos e deveres básicos ali expressos. Se ao concluírem o

RC: 83278

Disponível em: https://www.nucleodoconhecimento.com.br/educacao/integralizadodo-instituto 
Ensino Médio ainda não dominam tais conhecimentos, resta acreditar que esses virão no decorrer da vida cidadã, em ocasiões de conflito, ou noutras mais amenas, se vierem, quando algum acontecimento afetar sua liberdade ou seus bens (DIAS e DE OLIVEIRA, 2015).

Figura 18: Resultado das questões sobre Noções Básicas de Constituição Federal.

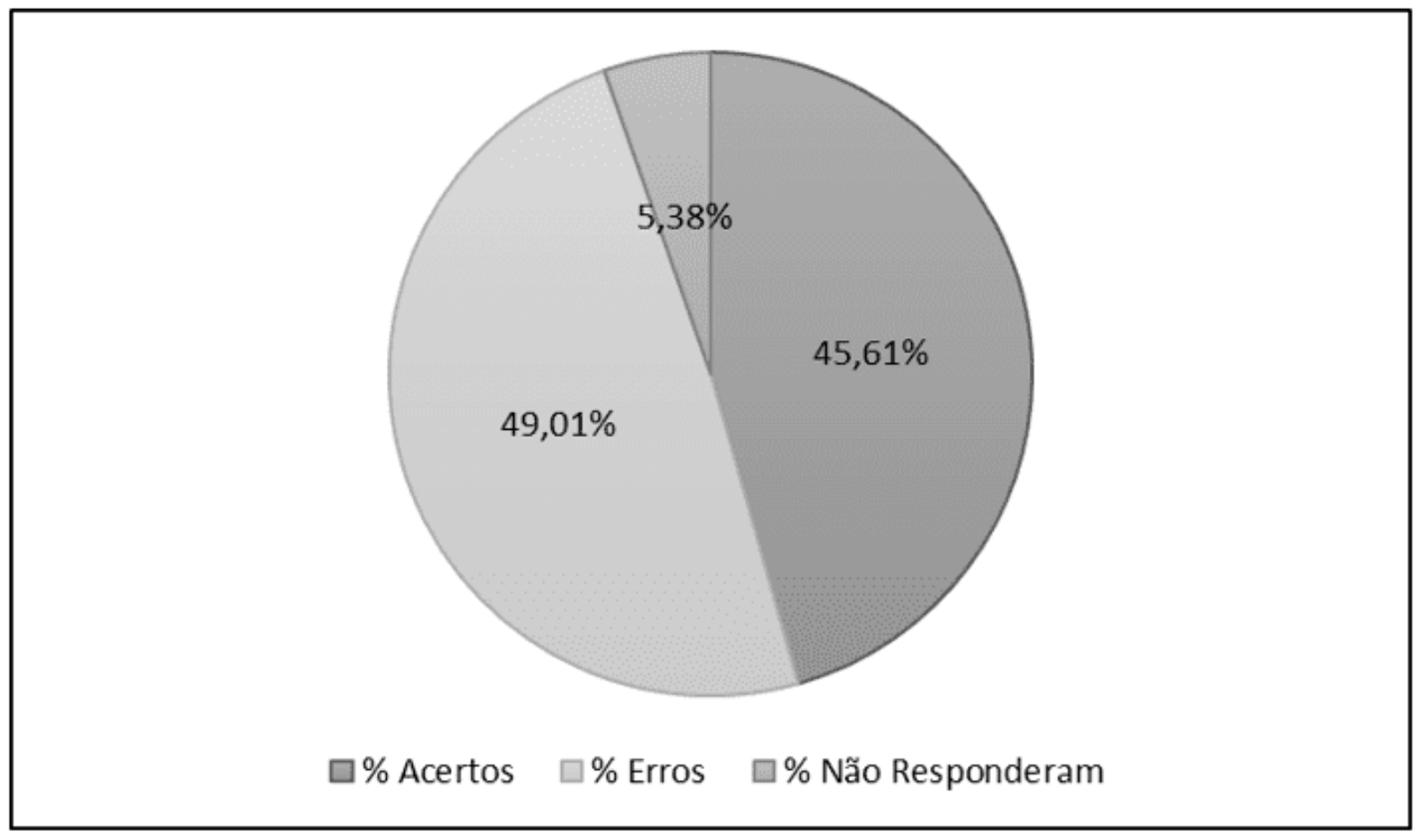

As figuras 19, 20, 21 e 22 abaixo apresentam os resultados das questões da seção sobre Noções Básicas de Constituição Federal com relação aos fatores de idade, série/ano, sexo e renda familiar, respectivamente. Nestes resultados constatamos o percentual de acertos em relação as respostas das questões sobre noções básicas da CF segundo os critérios pesquisados. 
Figura 19 Percentual de acertos sobre noções básicas da CF segundo a idade.

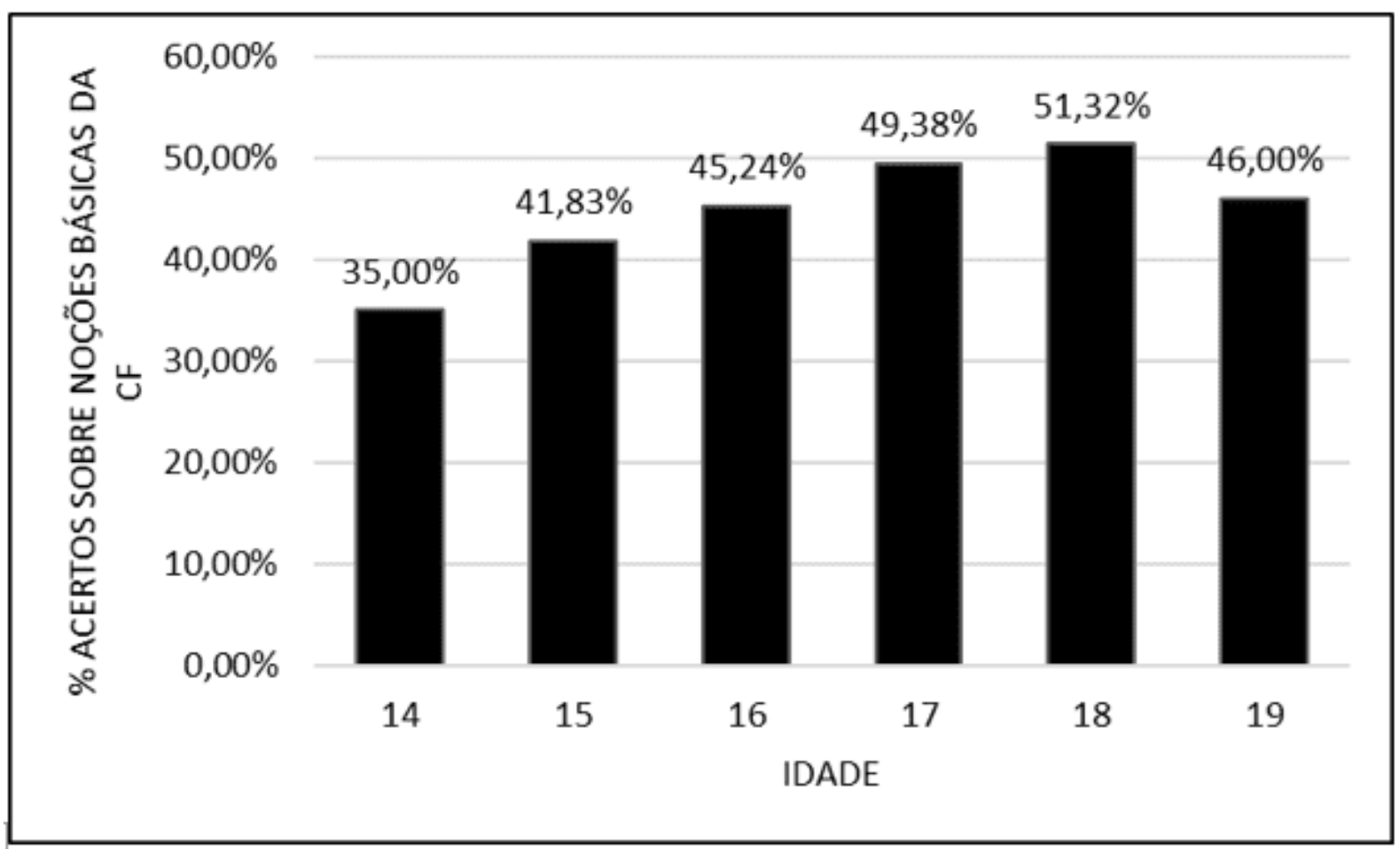

RC: 83278

Disponível em: https://www.nucleodoconhecimento.com.br/educacao/integralizadodo-instituto 
Figura 20 Percentual de acertos sobre noções básicas da CF segundo a série/ano.

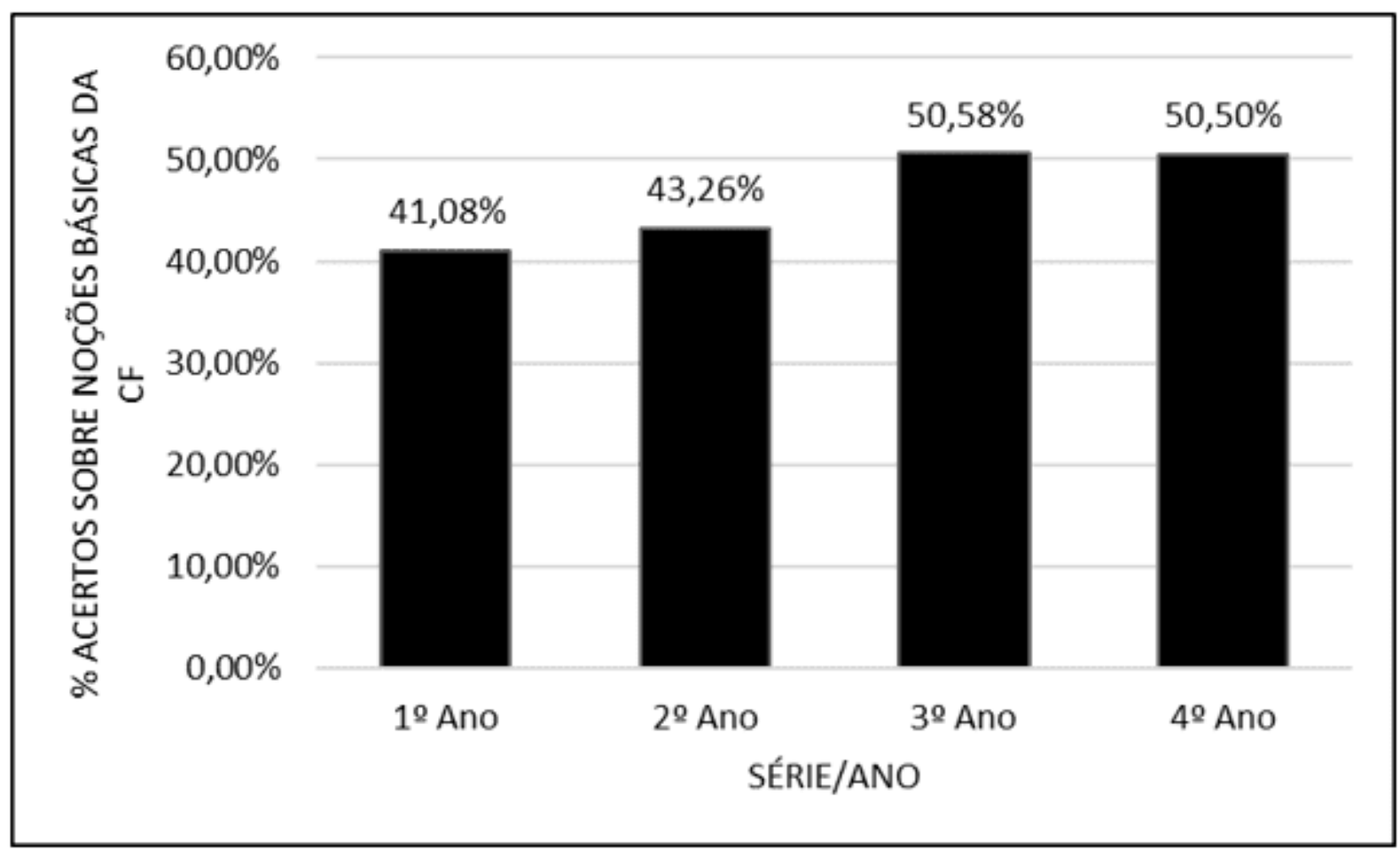

RC: 83278

Disponível em: https://www.nucleodoconhecimento.com.br/educacao/integralizadodo-instituto 
Figura 21 Percentual de acertos sobre noções básicas da CF segundo o sexo.

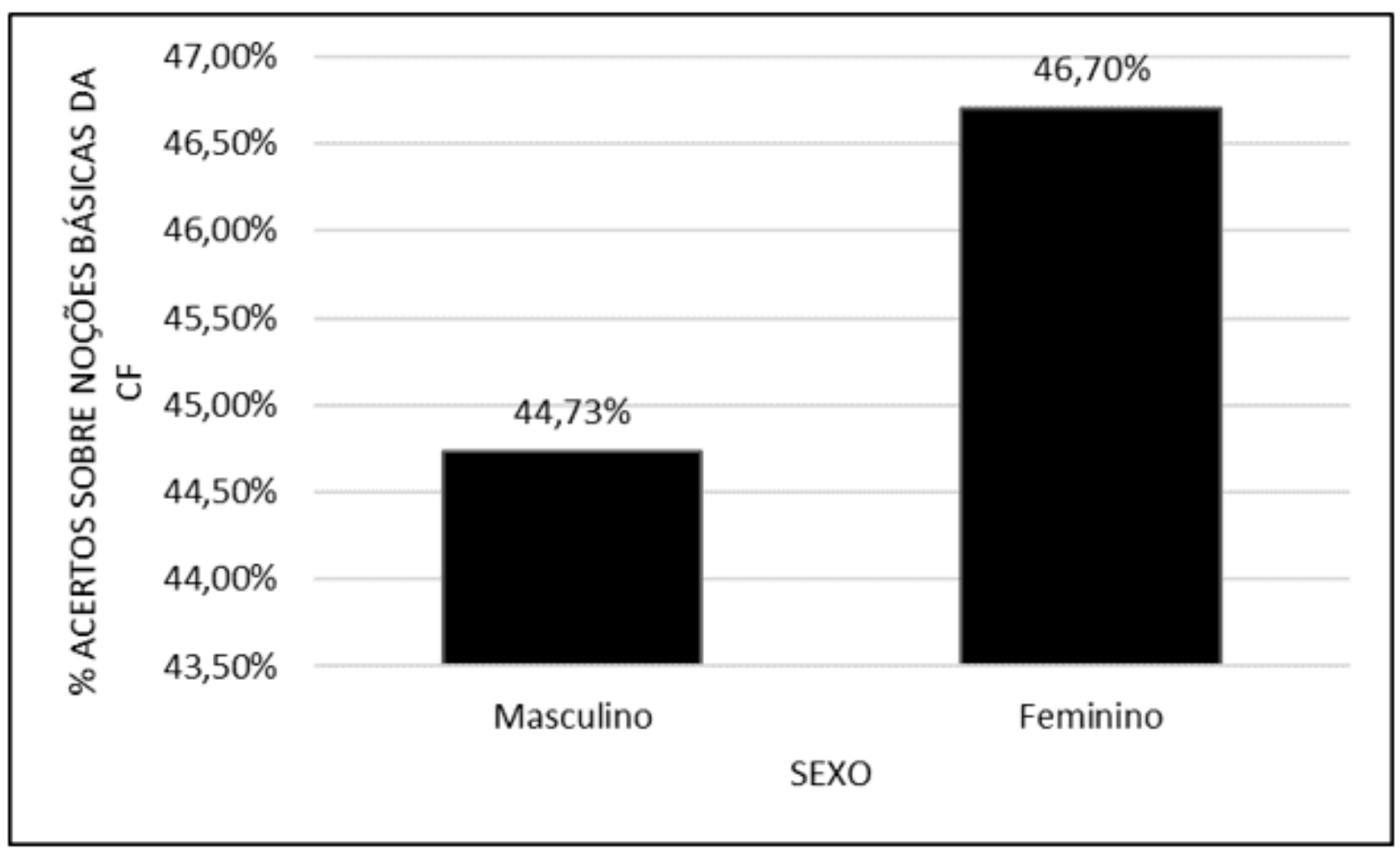

RC: 83278

Disponível em: https://www.nucleodoconhecimento.com.br/educacao/integralizadodo-instituto 
Figura 22 Percentual de acertos sobre noções básicas da CF segundo a renda familiar.

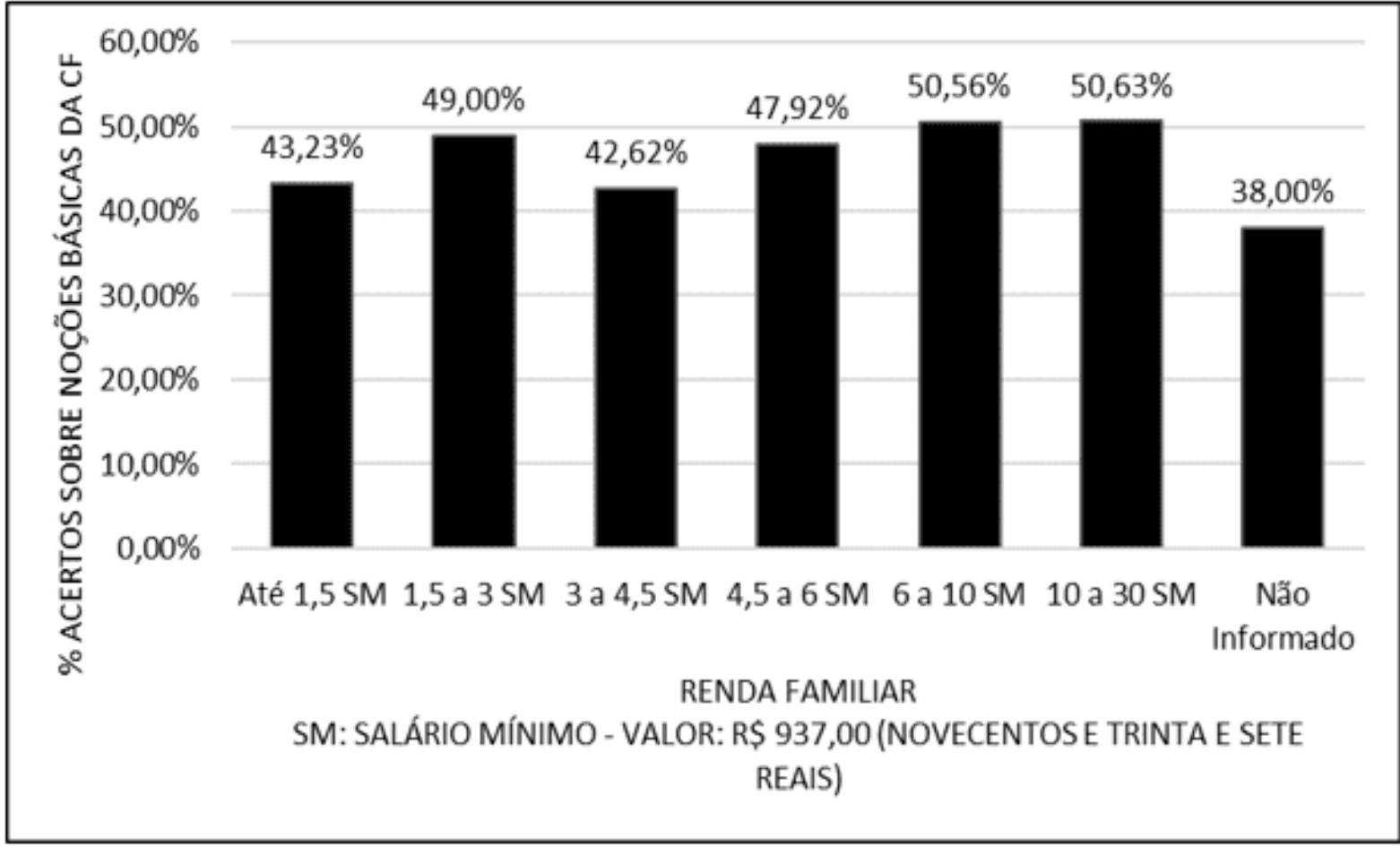

Apesar dos gráficos da figura 19 e 20 apresentarem algumas distorções em suas linhas de tendência, podemos notar um maior percentual de acertos à medida que os alunos vão avançando para a série seguinte e, consequentemente, apresentam uma idade mais elevada, isso é resultado de um maior convívio social por parte dos pesquisados. A distorção das duas últimas colunas dos dois gráficos supramencionados reflete, provavelmente, o descaso de parte destes alunos com o questionário ou pelo fato de serem, em sua maioria, alunos repetentes que não demostram interessem no processo de ensino e aprendizagem da instituição (ALMEIDA e ALVES, 2021).

Também podemos notar na figura 21 um equilíbrio nos acertos dos entrevistados do sexo masculino e feminino, o que reflete que esse fator não interfere diretamente nos resultados obtidos. Quanto a figura 22, verificamos uma leve tendência dos entrevistados com renda familiar maior em apresentar um índice de acertos maior,

RC: 83278

Disponível em: https://www.nucleodoconhecimento.com.br/educacao/integralizadodo-instituto 
mas essa influência não é muito significativa e pode ser facilmente questionada (FERREIRA e LEISMANN, 2020).

O resultado da figura 23 mostra que a maior parte dos entrevistados demonstram possuir princípios de justiça e filosofia que são essenciais para o convívio social não apresentando contradições em seus princípios, apesar de detectarmos algumas respostas contraditórias e em branco de alguns entrevistados.

Figura 23 Percentual de estudantes que demonstram possuir algum princípio de justiça e filosofia. Figura 24 Percentual de estudantes que responderam as respostas com influência de seu convívio social.

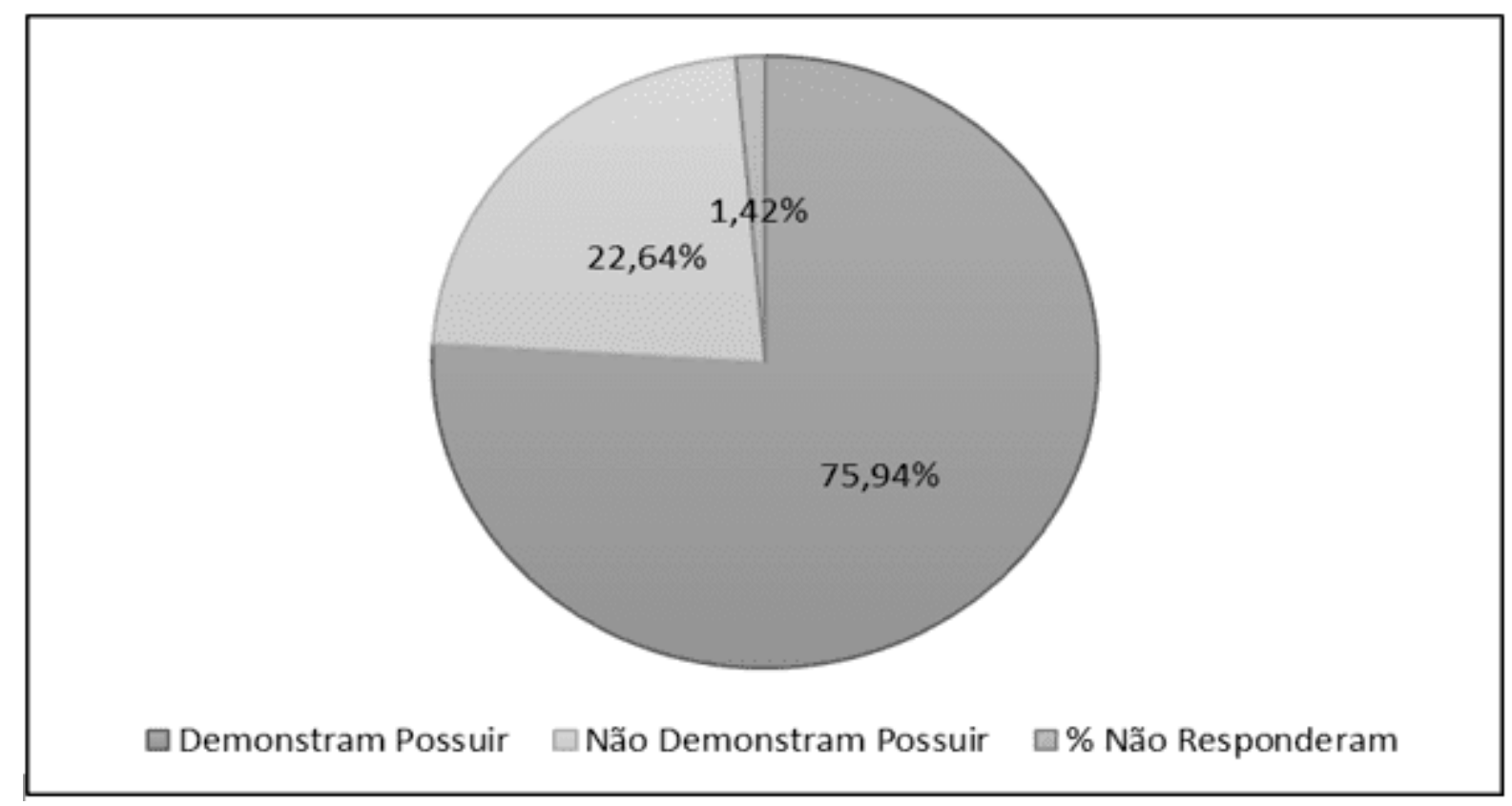

RC: 83278

Disponível em: https://www.nucleodoconhecimento.com.br/educacao/integralizadodo-instituto 
A figura 24 demonstra que poucos alunos tem a pretensão de cursar direito, isso já era esperado, uma vez que os entrevistados cursam edificações, curso da área de exatas, refletindo que a intenção de cursar Direito não influenciou significativamente nas respostas obtidas.

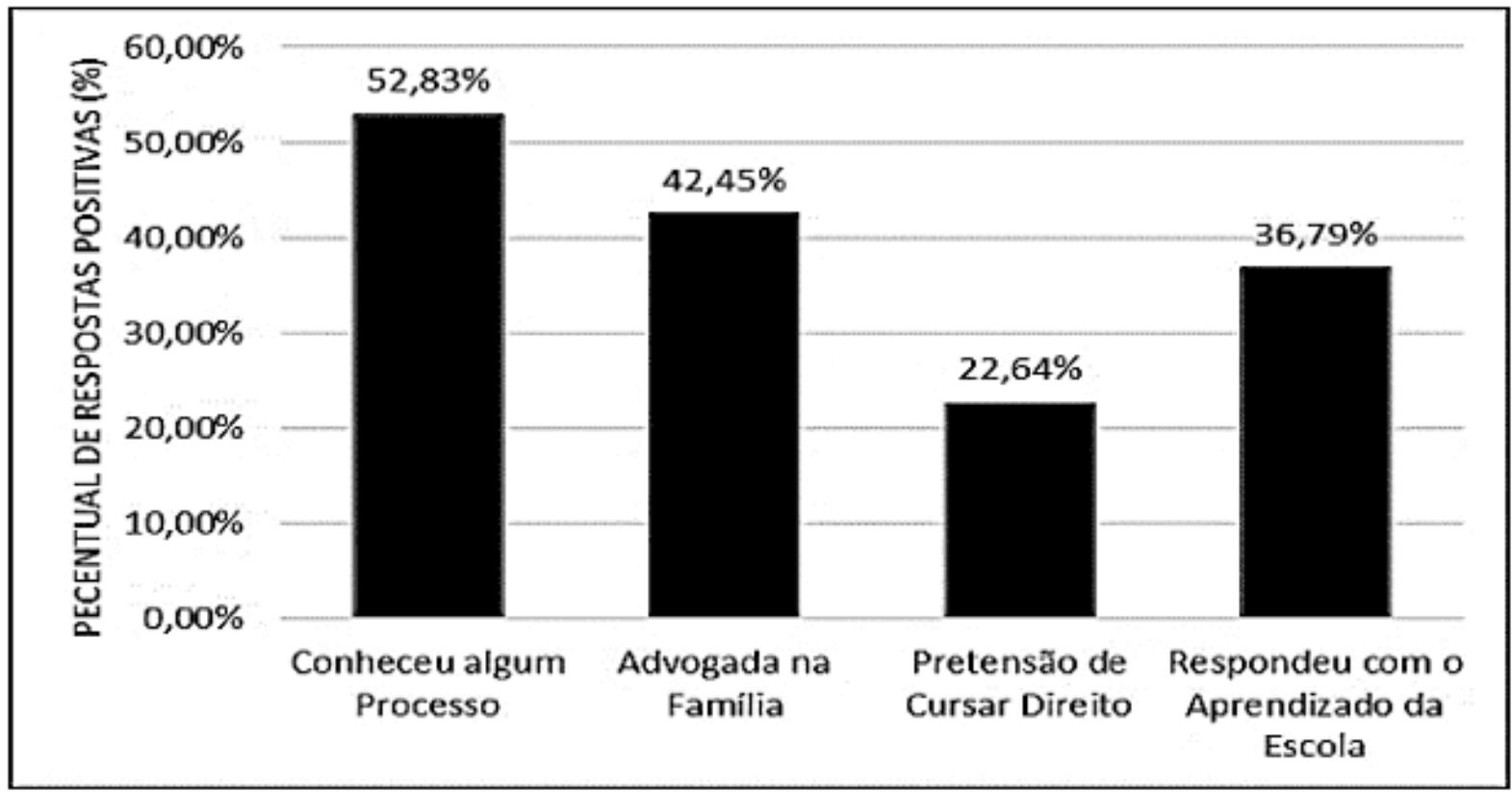

Por outro lado, evidenciamos que $52,83 \%$ dos entrevistados já presenciaram um processo judicial em alguma etapa de sua vida, o que pode ter contribuindo em suas respostas, isso é um alerta para a sociedade, pois cada vez mais cedo é essencial que os cidadãos tenham conhecimentos básicos de Direito, uma vez que irão precisar desses conhecimentos no seu cotidiano (LOTTERMANN et al., 2020).

O ponto negativo é que poucos estudantes confirmaram que responderam as questões do questionário com o que aprenderam na escola, demonstrando uma falha no ensino, visto que a função social da escola é a propagação e democratização dos conhecimentos necessários para a formação de cidadãos conscientes, participativos e atuantes na sociedade, e tendo como princípios e objetivos da República Federativa do Brasil na construção de uma sociedade livre, justa e solidária (LOTTERMANN et al., 2020).

RC: 83278

Disponível em: https://www.nucleodoconhecimento.com.br/educacao/integralizadodo-instituto 
Apesar da Figura 25 demonstrar que apenas $35,85 \%$ dos estudantes entrevistados realizaram algum comentário, todos os comentários escritos nesta seção, de uma maneira geral, foram positivos. Entre os comentários dos estudantes houve uma homogeneidade de gênero e para as turmas mais avançadas, obtínhamos sempre um número menor de comentários.

Figura 25 Percentual de estudantes que comentaram o questionário.

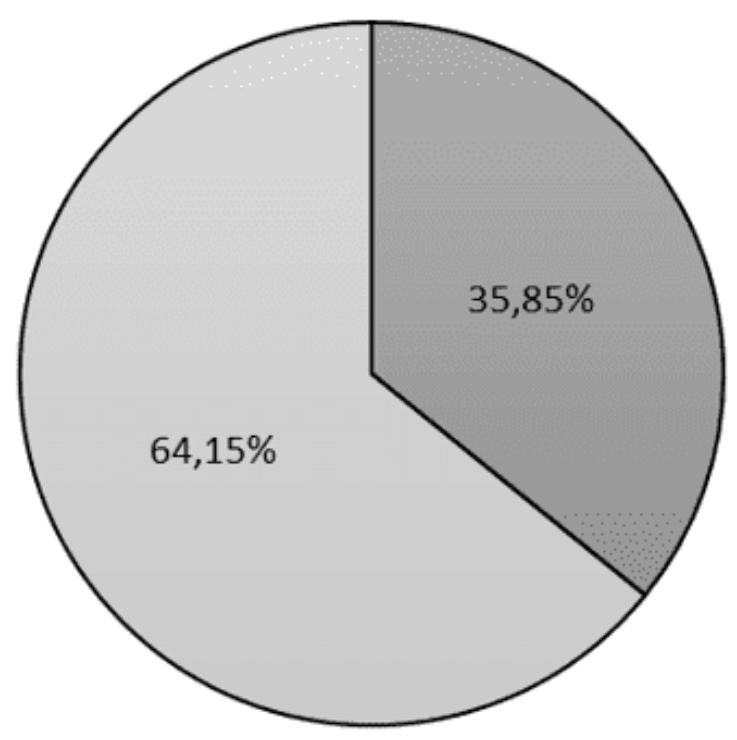

$\square \%$ Comentários $\quad \square \%$ Sem Comentários

A maioria dos comentários registrados relatou que o questionário foi muito interessante e bem elaborado, corroborando com a relevância do estudo da CF nas escolas. Também detectamos que alguns alunos despertaram para a falta de conhecimento sobre o assunto, relatando que nunca aprenderam isso na escola (MORAES, 2013).

Tivemos alguns comentários inesperados, como o fato de um aluno não residir no município de Macapá, dificultando suas respostas sobre a localização espacial dos poderes. Outro comentário afirmou que o questionário despertou maior apreço do aluno pelo curso de Direito, o qual o mesmo pretende ingressar, sem falar nas

Disponível em: https://www.nucleodoconhecimento.com.br/educacao/integralizadodo-instituto 
brincadeiras, típicas de alunos nesta faixa etária, utilizando palavras como: "top", dez, etc., para descrever o questionário.

\section{CONCLUSÕES}

Apesar dos diferentes projetos realizados até 0 momento em relação à implementação do Direito nas escolas de nível básico, este esforço ainda não conseguiu atingir a totalidade da Nação brasileira, mas é um esforço a ser praticado com responsabilidade e esperança a caminho de uma transformação social.

Percebeu-se a boa vontade da maioria dos sujeitos envolvidos em mudar a realidade brasileira por meio do ensino de uma disciplina de vital importância. Isso foi constatado nos resultados dos questionários, acreditando que a própria aplicação deles foi bastante salutar, pois suscitou debates e dúvidas entre os envolvidos, o que acabou, de certa forma, qualificando os participantes.

O Ensino Médio brasileiro, examinado a partir de um recorte pontual no curso técnico em edificações na forma integralizada do IFAP, campus Macapá, não consegue cumprir o que preconiza a CF e a LDB de acordo com o resultado do questionário aplicado aos estudantes. Este Ensino ocupa um lugar privilegiado na formação educacional brasileira, entre o fundamental e o superior.

Os alunos demonstram estar entusiasmados com a possibilidade de implementação do ensino de Noções Básicas a CF no curso técnico em edificações no IFAP, campus Macapá, mesmo que de forma optativa.

\section{REFERENCIAS}

ALMEIDA, F. A.; ALVES, M. T. G. A cultura da reprovação em escolas organizadas por ciclos. Revista Brasileira de Educação, v. 26, p. 1-28, 2021. 
AMARAL, D. P. D.; CASTRO, M. M. D. Educação moral e cívica: A retomada da obrigatoriedade pela agenda conservadora. Cad. Pesqui., v. 50, n. 178, p. 10781096, 2020.

ANTONELLO, I. P.; NOREMBERG, A. DIREITO E EDUCAÇÃO: a promoção da cidadania nas escolas brasileiras utilizando-se da disciplina de direito constitucional. XII Seminário De Demandas Sociais E Políticas Públicas $\mathrm{Na}$ Sociedade Contemporânea. Santa Cruz do Sul RS: UNISC 2016.

BRASIL. LEI № 8.112, DE 11 DE DEZEMBRO DE 1990. Brasilia DF, 1990. Disponível em: < http://www.planalto.gov.br/ccivil_03/leis//8112cons.htm >. Acesso em: 17 mar 2021.

. Constituição da República Federativa do Brasil (1988). DEPUTADOS, C.

D. Brasília DF: Edições Câmara 2012.

. LDB: Lei de diretrizes e bases da educação nacional - Lei no 9.394, de 20 de dezembro de 1996. Brasília DF: Edições Câmara 2016.

. Novo Ensino Médio - DÚVIDAS. MEC. Brasilia DF: MEC 2017.

DIAS, L. S.; DE OLIVEIRA, L. B. Acesso à educação jurídica: pela inclusão do ensino jurídico na grade curricular do ensino regular. Rio de Janeiro RJ, 2015. Disponível em:

https://periodicos.ufrn.br/constituicaoegarantiadedireitos/article/viewFile/8159/5897 >. Acesso em: 13 jun. 2017.

FERREIRA, T. A.; LEISMANN, E. L. Lei anticorrupção: Conhecimento e percepção na academia a partir de diferentes condições socioeconômicas. Administração de Empresas em Revistas v. 2, n. 21, p. 216-234, 2020. 
FIGUEIREDO, C. B. D. As Funções Do Estado: O Princípio Da Separação De Poderes. XVIII Jornada e Mostra de Estudos Jurídicos e Sociais. Santa Rosa RS: Faculdades Integradas Machado De Assis: 44-48 p. 2019.

FONSECA, C. J. D.; FERNANDES, L. F. A importância do conhecimento contábil matemático para a ciência jurídica: Uma revisão integrativa. J Business Techn, v. 17, n. 3, p. 116-135, 2020.

HOHENDORFF, R. V. et al. "Você Sabia? O Direito te Desafia!": Relato de Caso do Uso de Jogo de Tabuleiro com Cartas para Demonstrar a Alunos de Ensino Médio o Quanto o Direito pode ser Instigante. Anais do V Congresso sobre Tecnologias na Educação (Ctrl+E 2020). João Pessoa PB 2020.

IBGE. População - Distribuição da população por sexo. Brasilia DF, 2010. Disponível em: < https://brasilemsintese.ibge.gov.br/populacao/distribuicao-dapopulacao-por-sexo.html >. Acesso em: 17 mar 2021.

. Contas nacionais - PIB per capita. Brasilia DF, 2021. Disponível em: < https://brasilemsintese.ibge.gov.br/contas-nacionais/pib-per-capita.html >. Acesso em: 17 mar 2021.

IFAP. Resolução no 67.2019 Consup. Macapa AP: IFAP 2019.

Histórico. Macapa AP, 2021. Disponível em: < https://www.ifap.edu.br/index.php/quem-somos/historico >. Acesso em: 17 mar 2021.

LORENSET, R. B. C. et al. Direito e linguagem se (entre)laçam e se (con)fundem. Anuário Pesquisa e Extensão Unoesc Xanxerê, v. 6, p. 1-6, 2021.

LOTTERMANN, O.; SIQUEIRA, E.; CESARO, I. A. D. Mediações Do Conhecimento Escolar De Ensino Médio Com O Conhecimento Científico, O Mundo Do Trabalho E O Exercício Da Cidadania. Contexto \& Educação, n. 112, p. 200-216, 2020. 
MORAES, E. D. F. R. M. A importância da introdução de disciplinas jurídicas no ensino médio. Magistro, v. 8, n. 2, p. 27-45, 2013. Disponível em: < http://publicacoes.unigranrio.edu.br/index.php/magistro/article/view/2119/997 >.

NÓBREGA, V. V. D.; CORRÊA, C. S.; JESUS, J. C. D. Diferenciais De Gênero No Mercado De Trabalho Brasileiro Em 2016 E 2017. Campinas, SP, 2019. Disponível em: < https://abep.org.br/publicacoes/index.php/anais/article/viewFile/3556/3407 >. Acesso em: 17 mar 2021.

ROMARIO. Projetos de Lei. Brasilia DF, 2021. Disponível em: < https://romario.org/projetos/lei/ >. Acesso em: 17 mar 2021.

SARAIVA. Vade Mecum. 11. São Paulo SP: Saraiva, 2017.

SASSE, C. Pesquisa DataSenado mostra que poucos conhecem realmente a Constituição. 2013.

Disponível em:

http://www12.senado.leg.br/noticias/materias/2013/10/25/pesquisa-datasenadomostra-que-poucos-conhecem-realmente-a-constituicao-do-pais >. Acesso em: 4 out. 2017.

SILVA FILHO, N. A. Projeto OAB Vai à Escola continua se expandindo. São Paulo SP, 2004. Disponível em: < http://www.oabsp.org.br/noticias/2004/05/18/2413 >. Acesso em: 22 nov. 2017.

TAVARES, T. P.; MOTA, M. F.; FELDENS, D. G. O Ensino Moral E Cívico Como Princípios Educativos Na Formação Dos Cidadãos. Interfaces Científicas v. 8, n. 3, p. 422-433, 2020.

Enviado: Abril, 2021.

Aprovado: Abril, 2021. 